\title{
Chronic Lithium Chloride Administration Attenuates Brain NMDA Receptor-Initiated Signaling via Arachidonic Acid in Unanesthetized Rats
}

\author{
Mireille Basselin*,', Lisa Chang', Jane M Bell' and Stanley I Rapoport' \\ 'Brain Physiology and Metabolism Section, National Institute on Aging, National Institutes of Health, Bethesda, MD, USA
}

\begin{abstract}
It has been proposed that lithium is effective in bipolar disorder (BD) by inhibiting glutamatergic neurotransmission, particularly via $\mathrm{N}$-methyl-D-aspartate receptors (NMDARs). To test this hypothesis and to see if the neurotransmission could involve the NMDARmediated activation of phospholipase $A_{2}\left(P L A_{2}\right)$, to release arachidonic acid $(A A)$ from membrane phospholipid, we administered subconvulsant doses of NMDA to unanesthetized rats fed a chronic control or LiCl diet. We used quantitative autoradiography following the intravenous injection of radiolabeled $A A$ to measure regional brain incorporation coefficients $k^{*}$ for $A A$, which reflect receptormediated activation of PLA 2 . In control diet rats, NMDA (25 and $50 \mathrm{mg} / \mathrm{kg}$ i.p.) compared with i.p. saline increased $k^{*}$ significantly in 49 and 67 regions, respectively, of the 83 brain regions examined. The regions affected were those with reported NMDARs, including the neocortex, hippocampus, caudate-putamen, thalamus, substantia nigra, and nucleus accumbens. The increases could be blocked by pretreatment with the specific noncompetitive NMDA antagonist MK-80I ((5R, IOS)-(+)-5-methyl-I0, II-dihydro-5H-dibenzo[a,d] cyclohepten-5, I0-imine hydrogen maleate) $(0.3 \mathrm{mg} / \mathrm{kg}$ i.p.), as well by a 6-week $\mathrm{LiCl}$ diet sufficient to produce plasma and brain lithium concentrations known to be effective in $\mathrm{BD}$. MK-80I alone reduced baseline values for $k^{*}$ in many brain regions. The results show that it is possible to image NMDA signaling via PLA 2 activation and AA release in vivo, and that chronic lithium blocks this signaling, consistent with its suggested mechanism of action in $\mathrm{BD}$.

Neuropsychopharmacology (2006) 31, 1659-1674. doi:I 0.1038/sj.npp. I 300920; published online 9 November 2005
\end{abstract}

Keywords: arachidonic acid; lithium; bipolar disorder; phospholipase $\mathrm{A}_{2}$; MK-80I; NMDA

\section{INTRODUCTION}

Lithium $\left(\mathrm{Li}^{+}\right)$has been used to treat bipolar disorder (BD) for about 50 years, but its mechanism of action is not agreed on (Barchas et al, 1994; Cade, 1999). One suggestion has been that it acts in part by inhibiting glutamatergic neurotransmission, particularly via $N$-methyl-D-aspartate (NMDA) receptors (NMDARs) (Bauer et al, 2003; Farber et al, 2002; Krystal et al, 2002; Stewart and Reid, 2002; Zarate $e t a l, 2003)$. Supporting this is evidence of disturbed markers of NMDA functioning in the BD brain (Itokawa et al, 2003; Mundo et al, 2003; Scarr et al, 2003), and data that drugs effective against $\mathrm{BD}$, such as lamotrigine, carbamazepine and valproic acid, have direct or indirect

\footnotetext{
*Correspondence: Dr M Basselin, Brain Physiology and Metabolism Section, National Institute on Aging, National Institutes of Health, Bldg 9, Room ISI26-MSC 0947, Bethesda, MD 20892, USA, Tel: + I 30 I 594 5522, Fax: + I 30I 402 0074, E-mail: mirvasIn@mail.nih.gov Received 13 April 2005; revised 25 August 2005; accepted 30 August 2005

Online publication: I September 2005 at http://www.acnp.org/citations/ Npp090 105050247/default.pdf
}

NMDA antagonist properties (Farber et al, 2002; Hough et al, 1996; Kubota et al, 1994; McIntyre et al, 2004; Zeise et al, 1991).

Ionotropic NMDARs, cation channels with a high permeability to $\mathrm{Ca}^{2+}$ when activated, consist of heterotetrameric assemblies of NR1, NR2A-D, and NR3 subunits. The subunits are assembled cotranslationally in the endoplasmic reticulum, from where they are transported and then inserted at glutamatergic synapses. Release of NMDARs from the endoplasmic reticulum requires phosphorylation of NR1 and NR2 by protein kinases A and C (PKA and PKC), or by serine or tyrosine kinases (Scott et al, 2003; Wenthold et al, 2003). Binding of glutamate or NMDA to synaptic NMDARs allows $\mathrm{Ca}^{2+}$ into the cell to activate $\mathrm{Ca}^{2+}$-dependent enzymes such as calcium/calmodulindependent protein kinase II (CaMKII), PKC, phospholipase $\mathrm{C} \gamma$, and phospholipase $\mathrm{A}_{2}\left(\mathrm{PLA}_{2}\right)$ (Colbran, 2004; Fukunaga et al, 1992; Gurd and Bissoon, 1997; Weichel et al, 1999; Wenthold et al, 2003).

Exposure of neurons from different brain regions to NMDA is reported to activate $\mathrm{PLA}_{2}$ through the $\mathrm{Ca}^{2+}$ mechanism, to release the second messenger, arachidonic acid (AA, 20:4 n-6), from membrane phospholipid 
(Dumuis et al, 1988; Kim et al, 1995; Kolko et al, 1999, 2003; Lazarewicz et al, 1990; Pellerin and Wolfe, 1991; Sanfeliu et al, 1990; Tapia-Arancibia et al, 1992; Tencé et al, 1994; Weichel et al, 1999). The AA release could be blocked by the nonspecific $\mathrm{PLA}_{2}$ inhibitor, mepracrine, or in the rat hippocampus by bilobalide, a constituent of Ginkgo biloba, and by a specific inhibitor of $\mathrm{CPLA}_{2}$ (cytosolic $\mathrm{PLA}_{2}$ ) (see below) (Sanfeliu et al, 1990; Tapia-Arancibia et al, 1992; Tencé et al, 1994; Weichel et al, 1999). In contrast, NMDA did not stimulate AA release in hippocampal astroglia (Sanfeliu et al, 1990).

Optical methods have been used to image the $\mathrm{Ca}^{2+}$ signal in response to exogenous NMDA in brain slices or cell culture (Hashimoto et al, 2002; Ismailov et al, 2004; Mainen et al, 1999; Takita et al, 1997). However, no method exists, as far as we know, to image the $\mathrm{Ca}^{2+}$ signal or its downstream effects in the brain in vivo. In this paper, we present such a method, which extends our published method of imaging brain $\mathrm{PLA}_{2}$ activation in unanesthetized rats given drugs that act at receptors coupled a G-protein to $\mathrm{PLA}_{2}$ (Basselin et al, 2005a, b, 2003; Bhattacharjee et al, 2005; DeGeorge et al, 1991; Qu et al, 2003) - cholinergic muscarinic $M_{1,3,5}$, dopaminergic $D_{2}$-like and serotonergic $5-\mathrm{HT}_{2 \mathrm{~A} / 2 \mathrm{C}}$ receptors (Axelrod, 1995; Bayon et al, 1997; Felder et al, 1990; Vial and Piomelli, 1995).

There are three classes of brain $\mathrm{PLA}_{2}$ enzymes: AAselective $\mathrm{Ca}^{2+}$-dependent $\mathrm{CPLA}_{2}, \mathrm{sPLA}_{2}$ (secretory $\mathrm{PLA}_{2}$ ), and $\mathrm{iPLA}_{2}\left(\mathrm{Ca}^{2+}\right.$-independent $\left.\mathrm{PLA}_{2}\right)$ (thought to be selective for docosahexaenoic acid (DHA, 22:6n-3) rather than AA). All have been identified in neurons (Kishimoto et al, 1999; Strokin et al, 2004; Yang et al, 1999; Yegin et al, 2002). cPLA 2 has been localized at postsynaptic neuronal membranes in the brain (Basavarajappa et al, 1998; Ong et al, 1999; Pardue et al, 2003) and is activated by $300 \mathrm{nM}$ to $1 \mu \mathrm{M} \mathrm{Ca}^{2+}$ (Clark et al, 1995), in the physiological range of intracellular $\mathrm{Ca}^{2+}$ during neuronal activation (Ismailov et al, 2004). sPLA $\mathrm{PL}_{2}$ is activated at much higher $\mathrm{Ca}^{2+}$ concentrations, 16-18 mM (Dennis, 1994), and is localized in presynaptic vesicles that are released by exocytosis during membrane depolarization (Matsuzawa et al, 1996; Wei et al, 2003).

In elaborating our in vivo fatty acid imaging method when stimulating receptors coupled to $\mathrm{PLA}_{2}$ (see above), we concluded that a fraction of the AA that is released following $\mathrm{PLA}_{2}$ activation is rapidly reincorporated into phospholipid, whereas the remainder is lost by conversion to eicosanoids or other products, or by $\beta$-oxidation (Rapoport, 2001, 2003; Robinson et al, 1992). Unesterified AA in plasma rapidly replaces the quantity lost, as AA is nutritionally essential and cannot be synthesized de novo in vertebrate tissue or elongated significantly from its precursor, linoleic acid (18:2 n-6) (DeMar et al, 2004b; Holman, 1986; Washizaki et al, 1994). Replacement is proportional to $\mathrm{PLA}_{2}$ activation and can be imaged by injecting radiolabeled AA intravenously, then measuring regional brain radioactivity by quantitative autoradiography. A regional AA incorporation coefficient $k^{*}$ (regional brain radioactivity/integrated plasma radioactivity), calculated in this way, has been shown to be independent of changes in cerebral blood flow and to represent the plasmaderived AA reincorporated into brain phospholipid (Basselin et al, 2003; Chang et al, 1997; DeGeorge et al, 1991;
DeMar et al, 2004a; Rapoport, 2001, 2003; Robinson et al, 1992).

We thought it important to see if we could image brain AA signaling in response to NMDA, and if chronic $\mathrm{LiCl}$ would attenuate this signaling. In this study, we injected radiolabeled AA intravenously into unanesthetized rats to determine $k^{*}$ for AA in each of 83 brain regions in response to i.p. saline, and to each of two i.p. doses of NMDA, 25 and $50 \mathrm{mg} / \mathrm{kg}$, neither of which is reported to produce convulsions although capable of inducing paroxysmal EEG activity (Ormandy et al, 1991). We also imaged regional $k^{*}$ responses to the selective noncompetitive NMDA antagonist, MK-801 ((5R,10S)-(+)-5-methyl-10,11-dihydro-5H-dibenzo[a,d]cyclohepten-5,10-imine hydrogen maleate) (Wong et al, 1986, 1988), given at a dose of $0.3 \mathrm{mg} / \mathrm{kg}$ i.p. alone or prior to NMDA administration. Alone, this dose is reported to produce ataxia, hyperlocomotion, and stereotypies (Dai et al, 1995) accompanied by cortical spikewave discharges (Feinberg et al, 1995). Finally, we measured $k^{\star}$ for AA in response to NMDA in animals fed a control or $\mathrm{LiCl}$ diet for 6 weeks. The $\mathrm{LiCl}$ diet produces plasma and brain lithium concentrations of about $0.8 \mathrm{mM}$, reported to be therapeutic in BD (Basselin et al, 2003; Bosetti et al, 2002b; Calabrese et al, 1995; Chang et al, 1996). An abstract of part of this work has been presented (Basselin et al, 2004).

\section{MATERIALS AND METHODS}

\section{Animals and Diets}

Experiments were conducted following the 'Guide for the Care and Use of Laboratory Animals' (National Institute of Health Publication No. 86-23) and were approved by the Animal Care and Use Committee of the National Institute of Child Health and Development. Male Fischer CDF (F-344)/ CrlBR rats (2 months old) (Charles River Laboratories, Wilmington, MA) were fed a control or $\mathrm{LiCl}$ diet as previously described (Basselin et al, 2003).

\section{Drugs}

NMDA ( 25 or $50 \mathrm{mg} / \mathrm{kg}$, RBI Signaling Innovation, SigmaAldrich, Natick, MA), (+)-MK-801 hydrogen maleate $(0.3 \mathrm{mg} / \mathrm{kg}$, RBI Signaling Innovation) or $0.9 \% \mathrm{NaCl}$ (saline) was administered i.p. $\left[1-{ }^{14} \mathrm{C}\right] \mathrm{AA}$ in ethanol $(53 \mathrm{mCi} / \mathrm{mmol}$, $>98 \%$ pure, Moravek Biochemicals, Brea, CA) was evaporated and resuspended in HEPES buffer, $\mathrm{pH}$ 7.4, containing $50 \mathrm{mg} / \mathrm{ml} \mathrm{BSA}$, as described (DeGeorge et al, 1989). To confirm tracer purity, gas chromatography was performed after the $\left[1-{ }^{14} \mathrm{C}\right] \mathrm{AA}$ was converted to a methyl ester using $1 \mathrm{ml}$ of $1 \% \mathrm{H}_{2} \mathrm{SO}_{4}$ in anhydrous methanol (Makrides et al, 1994).

\section{Surgical Procedures and Tracer Infusion}

Surgery was performed as described (Basselin et al, 2003; Chang et al, 1996). A rat was wrapped loosely in a fastsetting plaster cast taped to a wooden block, and allowed to recover from anesthesia for 3-4h. Body temperature was maintained at $36.5^{\circ} \mathrm{C}$ using a feedback-heating device. Arterial blood pressure and heart rate were measured 
8 and $28 \mathrm{~min}$ after NMDA and MK-801 injection, respectively. Behavior was monitored immediately after drug administration until the end of the experiment. Repeated cycles consisting of an activity followed by a calm period were produced by NMDA. We measured the mean duration of each of these periods, as well as of the net cycling period.

At $10 \mathrm{~min}$ after NMDA or $30 \mathrm{~min}$ after MK-801 injection $\left[1-{ }^{14} \mathrm{C}\right] \mathrm{AA}(170 \mu \mathrm{Ci} / \mathrm{kg}, 2 \mathrm{ml}, 400 \mu \mathrm{l} / \mathrm{min})$ was infused for $5 \mathrm{~min}$ via the femoral catheter using an infusion pump (Harvard Apparatus Model 22, Natick, MA). For studies with both drugs, MK-801 was administered 30 min prior to NMDA, which in turn was given $10 \mathrm{~min}$ before $\left[1-{ }^{14} \mathrm{C}\right] \mathrm{AA}$. Timed arterial blood samples were collected during radiotracer infusion, to time of death at $20 \mathrm{~min}$, when the rat was killed using an overdose of sodium pentobarbital $(100 \mathrm{mg} / \mathrm{kg}$ i.v.) and immediately decapitated. The brain was removed and quickly frozen in 2-methylbutane at $-40^{\circ} \mathrm{C}$, stored at $-80^{\circ} \mathrm{C}$, and later sectioned for autoradiography.

\section{Chemical Analysis}

Plasma was separated from arterial blood by centrifugation, and lipids were extracted using a modification of Folch's method (DeGeorge et al, 1991; Folch et al, 1957). Total radioactivity in the organic phase was measured by liquid scintillation counting.

\section{Quantitative Autoradiography}

Quantitative autoradiography was performed as described previously (Basselin et al, 2003). A total of 83 brain regions were identified by comparing autoradiographs of coronal brain sections with a coronal atlas of the rat brain (Paxinos and Watson, 1987). The average of three bilateral optical density readings for each brain region from each animal was used to calculate regional radioactivity. Regional brain incorporation coefficients of AA from plasma into the stable brain lipid compartment, $k^{\star}(\mathrm{ml} / \mathrm{s} / g$ brain), were calculated as

$$
k *=\frac{c_{\text {brain }}^{*}(20 \mathrm{~min})}{\int_{0}^{20} c_{\text {plasma }}^{*} \mathrm{~d} t}
$$

where $c_{\text {brain }}^{*}(20 \mathrm{~min}) \mathrm{nCi} / g$ equals brain radioactivity at the time of death $(20 \mathrm{~min}), c_{\text {plasma }}^{*} \mathrm{nCi} / \mathrm{ml}$ equals plasma $\mathrm{AA}$ radioactivity determined by scintillation counting, and $t$ equals time after onset of infusion.

\section{Statistical Analyses}

In each of 83 brain regions, effects on $k^{\star}$ of NMDA and MK801 alone and in combination in control diet rats were compared to effects of saline by one-way ANOVA with Dunnett's post-test with correction for four comparisons, using GraphPad Prism version 3.0a for Macintosh (GraphPad Software, San Diego CA, www.graphpad.com). Corrections for multiple comparisons across regions were not made because this was an exploratory study (Bland, 2000) to identify the regions that were involved in individual drug effects. Additionally, a two-way ANOVA, comparing Diet (LiCl vs control) with Drug (NMDA vs saline), was performed for each region using SPSS 10.0 for Macintosh
(SPSS Inc., Chicago, IL, http://www.spss.com). At regions in which Diet $\times$ Drug interactions were statistically insignificant, probabilities of Main effects of Diet and Drug were separately calculated. At regions in which interactions were statistically significant, these probabilities were not calculated because they cannot be interpreted with certainty (Tabachnick and Fidell, 2001). Instead, unpaired $t$-tests were used to test for individual significant differences between means. Data are reported as means $\pm S D$, with statistical significance taken as $p \leqslant 0.05$.

\section{RESULTS}

\section{Physiological Parameters}

At the time of surgery, the LiCl-fed animals weighed significantly less than the control diet group $(257 \pm 42$ vs $299 \pm 15 \mathrm{~g}, \quad n=36, p<0.0001)$, as reported previously (Basselin et al, 2003).

In control diet rats, $25 \mathrm{mg} / \mathrm{kg}$ NMDA produced repeated cycles of head weaving and body movements lasting $4 \pm 1 \mathrm{~s}$ (activity period), following by a 'calm period' lasting $9 \pm 1 \mathrm{~s}$ (Table 1). The net time during which cycling continued was $90 \pm 15 \mathrm{~s}$. NMDA at $50 \mathrm{mg} / \mathrm{kg}$ also caused cycling, but with a significantly shorter 'calm period' $(5 \pm 2 s)$ than the lower dose, and a longer 'net cycling period' (180 $\pm 10 \mathrm{~s})$. No significant difference in cycling periods was observed in animals fed the $\mathrm{LiCl} v s$ those fed the control diet. MK-801 provoked head-weaving and body movements from $5 \mathrm{~min}$ after injection to the end of the experiment.

NMDA at both doses significantly decreased heart rate by about $20 \%$ in both control and $\mathrm{LiCl}$ diet groups, but did not significantly change arterial blood pressure, whereas MK801 increased arterial blood pressure by $30 \%$ in the control diet group (Table 1). Such changes, reported previously, have been ascribed to a centrally mediated increase in sympathetic nerve activity by MK-801 (Lewis et al, 1989). MK-801 given before NMDA abolished NMDA's significant effect on heart rate.

\section{Regional Brain AA Incorporation Coefficients, $k^{\star}$, in Control Diet Rats}

Plasma input function. As shown by equation (1), values of $k^{\star}$ for individual brain regions were calculated by dividing brain radioactivity by the brain exposure to plasma $\left[1-{ }^{14} \mathrm{C}\right] \mathrm{AA}$, the plasma input function equal to mean integrated arterial plasma radioactivity between 0 and 20 min. This function did not differ significantly between any groups. Mean integrated radioactivity, $\mathrm{nCi} / \mathrm{s} / \mathrm{ml}$, for control diet rats: saline $(159003 \pm 23885)$, NMDA $25 \mathrm{mg} / \mathrm{kg}$ $(162630 \pm 23409)$, NMDA $50 \mathrm{mg} / \mathrm{kg}(155796 \pm 12953)$, MK$8010.3 \mathrm{mg} / \mathrm{kg}(167647 \pm 16279)$, and MK-801 + NMDA $50 \mathrm{mg} / \mathrm{kg}(179785 \pm 10361)$, and for the $\mathrm{LiCl}$ diet rats: saline $(177699 \pm 14678)$, NMDA $25 \mathrm{mg} / \mathrm{kg}(166619 \pm 19830)$, NMDA $50 \mathrm{mg} / \mathrm{kg}(160236 \pm 15150)$. We have reported that chronic $\mathrm{LiCl}$ administration does not alter plasma unesterified fatty acid concentrations, including the AA concentration (Chang et al, 1999).

NMDA administration to control diet-fed rats. As illustrated in Figure 1, autoradiographs of coronal brain 
Table I Physiological Parameters and Behavior Activity Following Drug Administration in Unanesthetized Rats

\begin{tabular}{|c|c|c|c|c|c|c|}
\hline & NMDA 25 & NMDA 50 & MK-80I & NMDA 50+MK-80I & NMDA 25 & NMDA 50 \\
\hline \multicolumn{7}{|c|}{ Heart rate (beats/min) } \\
\hline Before & $447 \pm 32$ & $467 \pm 26$ & $480 \pm 0$ & $473 \pm 21$ & $427 \pm 20$ & $427 \pm 20$ \\
\hline After & $360 \pm 0$ ****** & $360 \pm 0 * * * *$ & $480 \pm 0$ & $473 \pm 21$ & $360 \pm 0$ ***** & $367 \pm 20 * * *$ \\
\hline \multicolumn{7}{|c|}{ Before } \\
\hline Systolic & $112 \pm 9$ & $106 \pm 5$ & $129 \pm 10$ & $121 \pm 4$ & $108 \pm 5$ & $113 \pm 7$ \\
\hline Diastolic & $83 \pm 7$ & $83 \pm 5$ & $84 \pm 10$ & $7 \mid \pm 8$ & $83 \pm 5$ & $82 \pm 7$ \\
\hline \multicolumn{7}{|l|}{ After } \\
\hline \multicolumn{7}{|c|}{ Behavior: duration (s) } \\
\hline \multicolumn{7}{|c|}{ Cycle } \\
\hline Activity & $4 \pm 1$ & $4 \pm 1$ & ND & ND & $4 \pm 1$ & $4 \pm 1$ \\
\hline Calm & $9 \pm 1$ & $5 \pm 2 * * * *$ & ND & ND & $10 \pm 1$ & $6 \pm 2 * * * *$ \\
\hline Net cycling & $90 \pm 15$ & $180 \pm 10 * * * *$ & ND & ND & $110 \pm 10$ & $190 \pm 15 * * *$ \\
\hline
\end{tabular}

ND, not determined

Data are presented as mean \pm SD $(n=9$ except for MK-80I + NMDA, $n=8)$.

***** $p<0.0001$.

sections from control rats showed that NMDA $50 \mathrm{mg} / \mathrm{kg}$ compared with saline generally increased $k^{\star}$ for AA whereas MK-801 generally decreased $k^{\star}$. There was no apparent difference between the autoradiographs from the LiCl-fed and control diet rat at baseline (i.p. saline), whereas NMDA in the LiCl-fed rat did not appear to have an effect on $k^{\star}$. Net regional data derived from the autoradiographs are presented in Tables 2 and 3 below.

As shown in Table 2, NMDA $(25 \mathrm{mg} / \mathrm{kg})$ compared with saline significantly increased $k^{*}$ for AA in $49 / 83$ regions examined (25 regions at $p<0.05$ and 24 regions at $p<0.001) . k^{*}$ was elevated significantly in the prefrontal, frontal, motor, somatosensory, auditory and visual cortical areas $(18-38 \%)$, olfactory tubercle (22\%), hippocampus (20-29\%), caudate-putamen (17-20\%), lateral geniculate nucleus dorsal (22\%), regions of the thalamus (15-20\%), and substantia nigra (20\%), with mean increments of $21.8 \pm 5.1 \%$ in these areas. Also, 67 of 83 regions, including the nucleus accumbens (39\%) (10 regions at $p<0.05$ and 57 regions at $p<0.001)$, showed significant increments in $k^{*}$ following $50 \mathrm{mg} / \mathrm{kg}$ NMDA compared with saline. Consistent with a dose-response relation, the mean of the significant increments equaled $30.6 \pm 8.0 \%$, which was significantly greater $(p<0.0001)$ than that following $25 \mathrm{mg} / \mathrm{kg}$ NMDA.

MK-801 in control diet rats. Compared with saline, MK801 given to control diet rats decreased $k^{*}$ for AA significantly in $21 / 83$ regions (Table 2, Figure 1), including the frontal cortex (16\%), pyriform cortex (20\%), preoptic area $(21 \%)$, suprachiasmatic nucleus $(24 \%)$, globus pallidus (25\%), hippocampus (21\%), thalamus (22-26\%), and hypothalamus (32-49\%). The mean reduction in the significantly affected regions was $29.8 \pm 10.9 \%$.

MK-801 followed by NMDA in control diet rats. In control diet rats, MK-801 followed by NMDA $50 \mathrm{mg} / \mathrm{kg}$, when compared with saline decreased $k^{\star}$ significantly in $21 / 83$ regions, of which 17 showed a significant decrease following MK-801 alone (see above).

Insignificant Diet $\times$ Drug interactions: As illustrated in Table 3,18/83 regions had a statistically insignificant Diet $(\mathrm{LiCl}$ diet $v s$ control diet) $\times$ Drug (NMDA vs saline) interaction with regard to $k^{*}$ for $\mathrm{AA}^{*}$. In seven of the 18 , NMDA compared with saline had a significant positive main Drug effect on $k^{\star}$, elevating $k^{\star}$ to the same extent in both the control diet and LiCl-fed rats. In two of the 18 regions (preoptic area and thalamus posterior), $\mathrm{LiCl}$ compared with control diet had a significant main effect on $k^{\star}$, elevating $k^{\star}$ to the same extent following saline or NMDA injection. Of the 83 regions, 10 did not have a significant Drug or Diet main effect.

Significant Diet $\times$ Drug interactions: Diet $\times$ Drug interactions were statistically significant in $65 / 83$ regions, including the prefrontal, frontal, motor, pyriform, anterior cingulate, somatosensory and visual cortex, preoptic area, superchiasmatic nucleus, globus pallidus, hippocampus, caudate-putamen, habenular nucleus, lateral geniculate 


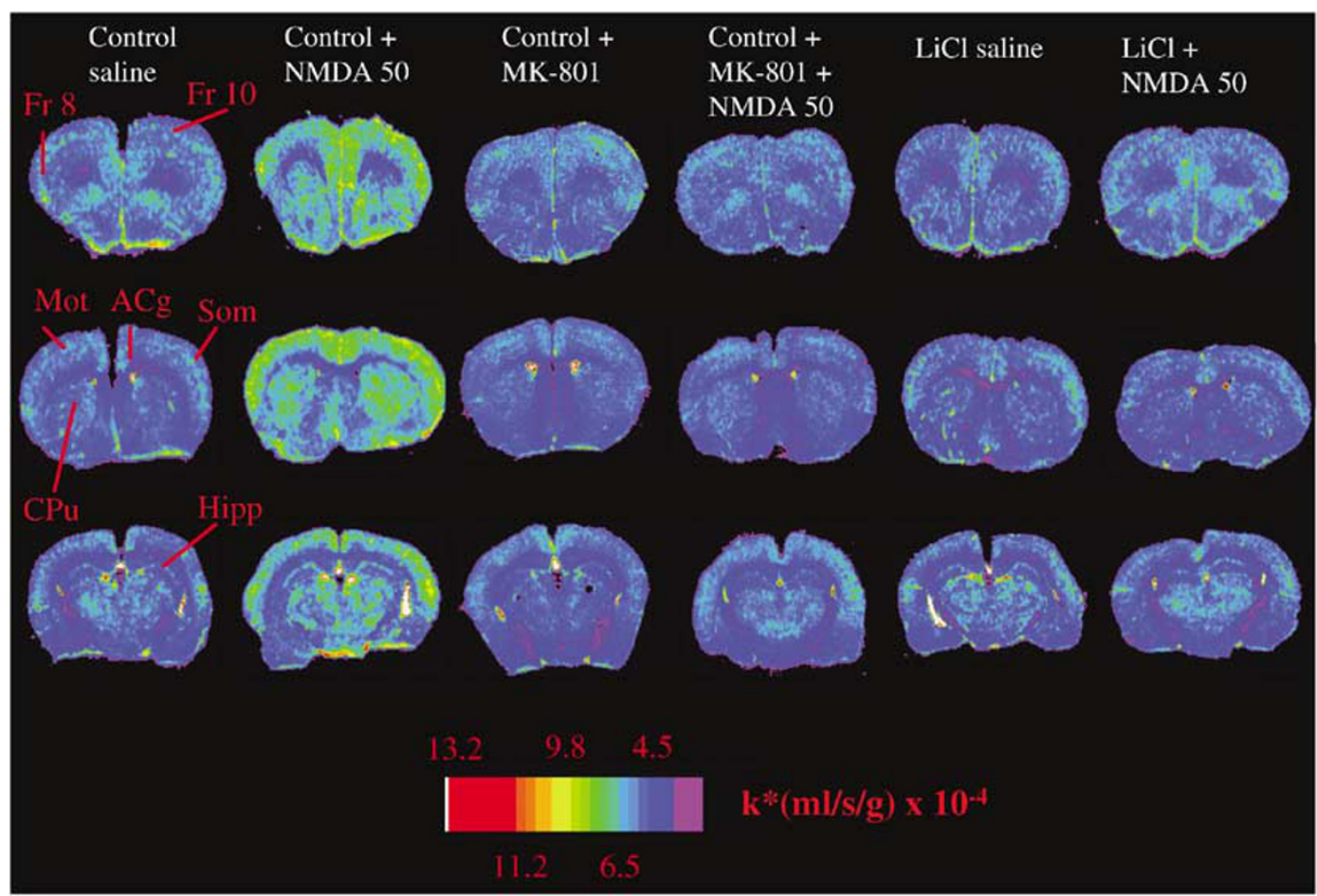

Figure I Effect of NMDA and MK-80 I on AA incorporation into brain of control and LiCl fed rats. Regional incorporation coefficients $k^{*}$ are illustrated in autoradiographs from coronal brain sections obtained $20 \mathrm{~min}$ after infusing $\left[\mathrm{I}-{ }^{14} \mathrm{C}\right] \mathrm{AA}$. Fr, frontal cortex; Mot, motor cortex; $\mathrm{ACg}$, anterior cingulated cortex; Som, somatosensory cortex; CPu, caudate putamen; Hipp, hippocampus.

nucleus dorsal, geniculate medial, areas of the thalamus and hypothalamus, substantia nigra, and inferior colliculus (Table 3). In 10 of the 65 regions, unpaired $t$-tests showed that the $\mathrm{LiCl}$ diet, compared to the control diet, elevated $k^{\star}$ significantly at baseline (in response to saline). These regions included visual cortex layers I, IV, and VI, lateral habenular nucleus, medial geniculate nucleus, and inferior colliculus, which belong to central auditory and visual pathways (Brodal, 1981). We reported this observation (Basselin et al, 2003, 2005b), and suggested that it may underlie lithium's ability in human subjects to increase the amplitudes of $\mathrm{P} 1 / \mathrm{N} 1$ components of auditory-evoked responses and of 65-P95 and P95-N125 components of visual-evoked responses (Fenwick and Robertson, 1983; Hegerl et al, 1990; Ulrich et al, 1990).

In 65/83 regions, NMDA increased $k^{\star}$ significantly in the control diet but not in the LiCl-fed rats. Thus, LiCl blocked $97 \%$ of the positive $k^{*}$ responses to $50 \mathrm{mg} / \mathrm{kg}$ NMDA $(65 / 67)$.

\section{DISCUSSION}

This study shows that (1) the in vivo fatty acid method (see Introduction) (Rapoport, 2001, 2003) can be used to image $\mathrm{PLA}_{2}$ activation coupled to NMDARs in unanesthetized rats; (2) regional increments in $k^{\star}$ for AA in response to subconvulsant NMDA doses in control diet rats are blocked by pretreatment with MK-801; (3) MK-801 alone (or when given prior to $50 \mathrm{mg} / \mathrm{kg}$ NMDA) produces widespread baseline reductions in $k^{*}$ for AA in control diet rats; and (4) a 6-week $\mathrm{LiCl}$ diet, sufficient to produce plasma and brain lithium concentrations therapeutically relevant to $\mathrm{BD}$ (Bosetti et al, 2002b; Chang et al, 1996), largely (97\%) prevents the significant NMDA-induced increments in $k^{\star}$ seen in control diet rats.

NMDA at 25 and $50 \mathrm{mg} / \mathrm{kg}$ significantly increased $k^{*}$ for $\mathrm{AA}$ by an average of $22 \%$ and $31 \%$, respectively, in significantly affected brain regions. These regions, reported to have NMDARs (Bernard and Bolam, 1998; Ikeda et al, 2003; Jarvis et al, 1987; Monaghan and Cotman, 1986; Pal et al, 1999; Petralia et al, 1994), included cerebral cortex, caudate-putamen, globus pallidus, hippocampus, substantia nigra, and nucleus accumbens. NMDA has also been reported to increase the regional cerebral metabolic rate for glucose, $\mathrm{rCMR}_{\mathrm{glc}}$, a marker of axonal activity (Sokoloff, 1999), in the rat suprachiasmatic nucleus (Shibata et al, 1992), frontal cortex layers V-VI, globus pallidus, caudateputamen, substantia nigra, thalamus, nucleus accumbens, and lateral habenular nucleus (Browne et al, 1998).

The blocking of increments in $k^{\star}$ for AA following NMDA by MK-801 is consistent with the increments being mediated by NMDARs. Furthermore, the ability of MK801 , given alone or prior to NMDA, to significantly reduce $k^{*}$ for AA by $16-49 \%$, suggests that NMDA-initiated $\mathrm{PLA}_{2}$ activation contributes substantially to the baseline release of AA in control brain. This interpretation is consistent with evidence that glutamatergic receptors constitute about $75 \%$ of the synapses in the mammalian cortex, and that many of these synapses include NMDARs (Braitenberg and Schüz, 1998; Fonnum, 1984; Raichle and Gusnard, 2002).

The increments in $k^{\star}$ for $\mathrm{AA}$ in response to the subconvulsant doses of NMDA were most likely due to enhanced $\mathrm{Ca}^{2+}$ entry into the cell via NMDARs, activating 
Table 2 Mean Values of Arachidonic Acid Incorporation Coefficients $k^{* a}$ in Control Diet-Fed Rats, at Baseline (in Response to Saline) and in Response to NMDA ${ }^{b}, M_{K}-80 I^{c}$, and MK-80I+NMDA ${ }^{\mathrm{d}}$

\section{Control diet}

\section{Brain region}

Telencephalon

Prefrontal cortex layer I

Prefrontal cortex layer IV

Primary olfactory cortex

Frontal cortex (10)

$$
\begin{aligned}
& \text { Layer I } \\
& \text { Layer IV }
\end{aligned}
$$

Frontal cortex (8)

$$
\begin{aligned}
& \text { Layer I } \\
& \text { Layer IV }
\end{aligned}
$$

Pyriform cortex

Anterior cingulate cortex

$$
\begin{aligned}
& \text { Motor cortex } \\
& \text { Layer I } \\
& \text { Layer II-III } \\
& \text { Layer IV } \\
& \text { Layer V } \\
& \text { Layer VI }
\end{aligned}
$$

Somatosensory cortex

$$
\begin{aligned}
& \text { Layer I } \\
& \text { Layer II-III } \\
& \text { Layer IV } \\
& \text { Layer V } \\
& \text { Layer VI }
\end{aligned}
$$

\section{Auditory cortex}

$$
\begin{aligned}
& \text { Layer I } \\
& \text { Layer IV } \\
& \text { Layer VI }
\end{aligned}
$$

$$
\begin{aligned}
& \text { Visual cortex } \\
& \text { Layer I } \\
& \text { Layer IV } \\
& \text { Layer VI }
\end{aligned}
$$

Preoptic area (LPO/MPO)

Suprachiasmatic nu

Globus pallidus

Bed nu stria terminalis

Olfactory tubercle

Diagonal band

\begin{tabular}{cll} 
Dorsal & $5.75 \pm 0.33$ & $7.04 \pm 0.82 * * * *$ \\
Ventral & $5.61 \pm 0.60$ & $6.96 \pm 0.84 * * *$ \\
Amygdala basolat/med & $5.28 \pm 0.95$ & $5.88 \pm 0.51$ \\
\hline
\end{tabular}

\begin{tabular}{ll}
$5.28 \pm 0.92$ & $7.29 \pm 1.00 * * *$ \\
$6.07 \pm 0.54$ & $7.74 \pm 0.94 * * *$ \\
$5.64 \pm 0.55$ & $7.09 \pm 0.86 * * *$ \\
& \\
$5.70 \pm 0.88$ & $6.56 \pm 0.71$ \\
$5.53 \pm 0.77$ & $6.50 \pm 0.77 *$ \\
$5.31 \pm 0.80$ & $6.38 \pm 0.75 *$ \\
$5.68 \pm 0.82$ & $6.44 \pm 0.94$ \\
$5.83 \pm 0.57$ & $7.12 \pm 0.55 * * *$ \\
& \\
& \\
$5.75 \pm 0.33$ & $7.04 \pm 0.82 * * *$ \\
$5.61 \pm 0.60$ & $6.96 \pm 0.84 * * *$ \\
$5.28 \pm 0.95$ & $5.88 \pm 0.51$ \\
\hline
\end{tabular}

Neuropsychopharmacology

\section{$6.37 \pm 0.61$}

$6.77 \pm 0.68$

$7.76 \pm 0.64$ ****

$\begin{array}{ll}6.46 \pm 0.59 & 8.04 \pm 0.69 * * * \\ 6.89 \pm 0.68 & 8.58 \pm 0.79 * * * * \\ 5.64 \pm 0.52 & 6.29 \pm 0.73 \\ 7.34 \pm 1.10 & 8.59 \pm 0.64 *\end{array}$

$6.43 \pm 0.67$

$6.54 \pm 0.68$

$6.88 \pm 0.77$

$5.31 \pm 0.44$

$5.25 \pm 0.55$

$7.57 \pm 0.54 *$
$7.78 \pm 0.49 *$
$8.40 \pm 0.81$ ****
$6.54 \pm 0.37 * * *$
$6.24 \pm 0.36 * * *$

$6.16 \pm 0.85$

$6.37 \pm 0.39$

$7.06 \pm 0.41$

$6.02 \pm 0.59$

$7.53 \pm 1.08$

$8.45 \pm 1.05$

$7.95 \pm 0.89 * * * *$
Saline $(n=9) \quad$ NMDA $25(n=9) \quad$ NMDA $50(n=9) \quad$ MK-80I $(n=9) \quad$ MK-80I+NMDA $50(n=8)$

$8.62 \pm 1.06 * * * *$

$8.87 \pm 0.90 * * *$

$5.69 \pm 0.40$

$6.85 \pm 0.63$

$8.35 \pm 1.35 * * * *$

$8.34 \pm 1.33 * * * *$

$9.22 \pm 1.36 * * * *$

$7.14 \pm 1.00 * * * *$

$6.90 \pm 0.93 * * *$

$5.95 \pm 0.08$

$6.03 \pm 0.33$

$6.60 \pm 0.38$

$4.99 \pm 0.33$

$4.73 \pm 0.32$

$9.15 \pm 1.6 * * *$

$9.00 \pm 1.30 * * * *$

$9.79 \pm 1.84 * * *$

$8.99 \pm 1.62 * * *$

$8.29 \pm 1.53$ ****

$7.75 \pm 2.37$
$8.74 \pm 2.31$ *
$8.01 \pm 1.55$ ****

$6.29 \pm 0.36$

$6.74 \pm 1.14$

$6.99 \pm 0.71$

$7.50 \pm 1.35$ ****

$7.97 \pm 1.54 * * * *$

$7.36 \pm 1.24 * * * *$

$6.82 \pm 0.69 *$

$5.55 \pm 0.99$

$6.42 \pm 0.69 * * *$

$6.98 \pm 0.50$ ****

$7.42 \pm 0.93$ ***

$6.12 \pm 0.95$

$6.51 \pm 0.81$

$5.93 \pm 0.98$

$4.49 \pm 0.66$ ****

$4.23 \pm 0.61$ 米米

$3.98 \pm 0.73$ ******

$4.16 \pm 0.56$ ****

$5.13 \pm 0.39$

$8.04 \pm 0.57$ *****

$8.04 \pm 0.87 * * *$

$6.42 \pm 0.64 * * * *$
$5.75 \pm 0.59$

$6.99 \pm 0.43$

$5.77 \pm 0.58$

$6.57 \pm 0.58$

$4.72 \pm 0.69 *$

$5.39 \pm 0.41$ *****

$5.98 \pm 0.31$

$4.13 \pm 0.77$ ****

$7.01 \pm 1.22$

$5.64 \pm 0.90$

$6.05 \pm 0.86$

$6.46 \pm 0.92$

$4.86 \pm 0.61$

$4.86 \pm 0.68$

$5.38 \pm 0.92$

$5.81 \pm 0.77$

$6.30 \pm 0.94$

$5.74 \pm 0.80$

$5.70 \pm 0.90$

$5.63 \pm 0.23$

$6.17 \pm 0.64$

$6.69 \pm 0.41$

$5.83 \pm 0.94$

$6.31 \pm 0.96$

$5.86 \pm 1.16^{\Delta}$

$4.46 \pm 0.88 * * * *$

$3.92 \pm 0.65$ *****

$3.92 \pm 0.67$ *****

$4.12 \pm 0.49$ ****

$5.04 \pm 0.69$

$5.10 \pm 0.76$

$4.70 \pm 0.64$

$4.18 \pm 0.72 *$ 
Table 2 Continued

Control diet

\section{Brain region}

Hippocampus

CAI

CA2

CA3

Dentate gyrus

SLM

Accumbens nucleus

Caudate putamen

Dorsal
Ventral
Lateral
Medial

Septal nucleus lateral Medial

Diencephalon

Habenular nu lateral Medial

Lat geniculate nu dorsal

Geneculate medial

Thalamus

Ventroposterior lat nu

Ventroposterior med nu

Paratenial nu

Anteroventral nu

Anteromedial nu

Reticular nu

Paraventricular nu

Parafascicular nu

Subthalamic nucleus

Hypothalamus

Supraoptic nu

Lateral

Anterior

Periventricular

Arcuate

Ventromedial

Posterior

Mammillary nucleus

\section{Mesencephalon}

Interpeduncular nucleus

Substantia nigra

$$
\text { Pars reticulata }
$$

Pars compacta

Pretectal area

$\begin{array}{ll}4.70 \pm 0.53 & 5.95 \pm 0.70 \text { ***** } \\ 4.99 \pm 0.78 & 6.03 \pm 0.61 \text { **** } \\ 5.34 \pm 0.93 & 6.23 \pm 0.68 * \\ 5.74 \pm 0.83 & 6.52 \pm 0.64 \\ 5.48 \pm 0.75 & 7.08 \pm 0.84 * * * * \\ 5.92 \pm 0.78 & 6.19 \pm 0.56\end{array}$

$6.17 \pm 0.57$

$6.11 \pm 0.64$

$6.06 \pm 0.60$

$6.12 \pm 0.69$

$5.61 \pm 0.74$

$5.93 \pm 0.49$

$7.00 \pm 0.95$

$7.22 \pm 0.78$

$6.42 \pm 0.46$

$6.28 \pm 0.81$

$6.28 \pm 0.47$

$6.09 \pm 0.44$

$6.52 \pm 0.67$

$7.68 \pm 1.10$

$6.51 \pm 0.66$

$6.55 \pm 0.56$

$6.58 \pm 0.72$

$6.06 \pm 0.56$

$6.51 \pm 0.61$

$5.31 \pm 0.60$

$5.93 \pm 0.61$

$5.79 \pm 0.63$

$6.34 \pm 0.39$

$5.79 \pm 1.12$

$5.61 \pm 0.96$

$6.34 \pm 0.39$

$6.03 \pm 0.78$

$8.18 \pm 0.69$

$5.57 \pm 0.43$

$5.57 \pm 0.47$

$6.39 \pm 0.61$

\section{$7.21 \pm 0.65 * * * *$ \\ $7.12 \pm 0.66 *$ \\ $7.28 \pm 0.68 *$ \\ $7.26 \pm 0.70 *$ \\ $6.16 \pm 0.63$ \\ $6.29 \pm 0.7 \mid$}

$6.16 \pm 0.44 * * *$

$6.58 \pm 0.44 * * *$

$6.66 \pm 0.44 * * *$

$7.54 \pm 1.16$ ****

$8.08 \pm 1.19 * * *$

$8.24 \pm 1.57$ ****

\begin{abstract}
$8.22 \pm 0.86$ ****
$8.25 \pm 1.04 * * *$

$8.32 \pm 1.15 * * *$

$8.21 \pm 0.96$ ***

$7.28 \pm 1.00 * * *$

$7.88 \pm 0.92 * * * *$
\end{abstract}
$9.50 \pm 2.63 *$
$9.45 \pm 2.65 *$
$8.92 \pm 1.03 * * *$
$7.96 \pm 2.08 *$

$7.74 \pm 0.94$
$7.52 \pm 0.79 * * *$

$7.54 \pm 0.64 * * *$

$8.64 \pm 1.31$ ****

$10.74 \pm 1.75 * * *$

$8.66 \pm 0.93 * * *$

$8.95 \pm 0.91 * * *$

$8.64 \pm 1.28 * * *$

$7.03 \pm 0.64 * * *$

$8.33 \pm 0.82 * * *$

\begin{abstract}
$6.76 \pm 0.99 * * *$
$6.72 \pm 0.84 *$

$6.72 \pm 0.82 *$

$7.84 \pm 0.97 * * * *$

$6.59 \pm 0.70$

$6.50 \pm 0.55 *$

$7.84 \pm 0.97 * * *$

$7.10 \pm 1.30$
\end{abstract}

$6.87 \pm 0.81$

$6.82 \pm 0.90$

$9.62 \pm 1.32$

$6.57 \pm 0.46 *$

$6.74 \pm 0.56 *$

$7.56 \pm 0.93$

$9.70 \pm 2.33$

$6.39 \pm 0.60$

$6.42 \pm 0.57$

$6.88 \pm 0.57$

$4.13 \pm 0.43$
$3.93 \pm 0.51 * * *$
$4.20 \pm 0.56 * * *$
$5.28 \pm 0.98$
$5.43 \pm 0.46$
$5.62 \pm 0.66$

$4.30 \pm 0.49$

$4.13 \pm 0.53 *$

$4.48 \pm 0.56 *$

$5.69 \pm 0.81$

$5.94 \pm 0.47$

$5.92 \pm 0.50$
$5.79 \pm 0.49$
$5.87 \pm 0.55$
$6.22 \pm 0.76$
$5.78 \pm 0.67$
$4.20 \pm 0.82 * * *$
$5.01 \pm 0.70 *$

$7.12 \pm 0.43$

$6.19 \pm 0.82$

$6.17 \pm 0.61$

$6.21 \pm 0.71$

$\begin{array}{ll}6.52 \pm 1.00 & 7.12 \pm 0.43 \\ 6.53 \pm 0.99 & 6.19 \pm 0.82 \\ 6.36 \pm 0.70 & 6.17 \pm 0.61 \\ 6.04 \pm 0.52 & 6.21 \pm 0.71\end{array}$

$\begin{array}{ll}5.52 \pm 0.93 & 5.90 \pm 0.86 \\ 5.60 \pm 0.94 & 5.44 \pm 0.55 \\ 4.88 \pm 0.52 * * * & 5.37 \pm 0.73^{*} \\ 6.18 \pm 0.69 & 7.19 \pm 1.00 \\ 5.06 \pm 0.58 * * * * & 5.67 \pm 0.55 \\ 5.14 \pm 0.61 * * * & 6.13 \pm 1.17 \\ 4.84 \pm 0.50 * * * & 5.35 \pm 0.54 * \\ 6.10 \pm 1.03 & 5.93 \pm 0.55 \\ 6.90 \pm 0.93 & 6.70 \pm 0.28\end{array}$

$4.16 \pm 1.11$
$4.05 \pm 0.58 * * *$
$3.94 \pm 0.64 * * *$
$3.21 \pm 0.55 * * * *$
$3.36 \pm 1.01$ ****
$3.49 \pm 0.93 * * * *$
$5.03 \pm 1.28$
$5.64 \pm 0.92$

$5.28 \pm 0.60$

$4.24 \pm 0.21$ *****

$4.37 \pm 0.17$ ****

$3.58 \pm 0.20$ ****

$3.10 \pm 1.32$ ****

$3.16 \pm 1.16$ ****

$3.37 \pm 1.12$ ****

$6.83 \pm 0.94$

$7.89 \pm 0.24$

$7.51 \pm 0.61$

$5.16 \pm 1.47$

$4.66 \pm 0.47$

$5.11 \pm 1.47$

$4.53 \pm 0.42 *$

$6.38 \pm 0.99$

$6.36 \pm 0.76$ 
Table 2 Continued

Control diet

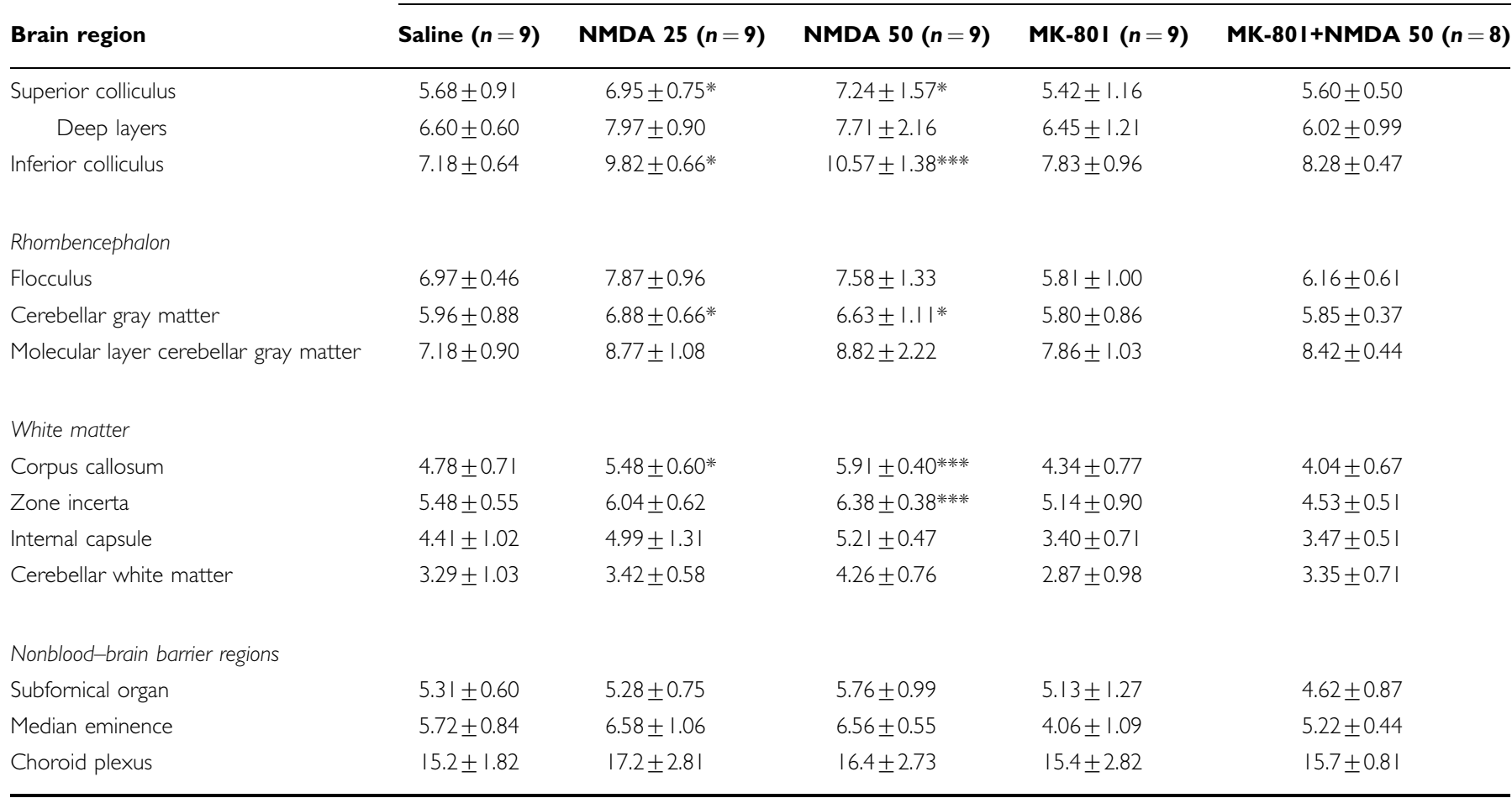

nu, nucleus; lat, lateral; med, medial; SLM, stratum lacunosum-moleculare of the hippocampus.

Each value is a mean $\pm S D$.

* $p<0.05$; **** $p<0.00$ I; compared with the saline group (one-way ANOVA Dunnett tests).

${ }^{a} k^{*}=(\mathrm{ml} / \mathrm{s} / \mathrm{g}) \times 10^{-4}$

DNMDA administration: 25 and $50 \mathrm{mg} / \mathrm{kg}$ i.p., $10 \mathrm{~min}$.

cMK-80I administration: $0.3 \mathrm{mg} / \mathrm{kg}$ i.p., $30 \mathrm{~min}$.

dMK-80 I +NMDA administration: $0.3 \mathrm{mg} / \mathrm{kg}$ i.p., $30 \mathrm{~min}$ followed by NMDA $50 \mathrm{mg} / \mathrm{kg}$ i.p., $10 \mathrm{~min}$.

$\mathrm{CPLA}_{2}$ to release AA from membrane phospholipid. NMDAprovoked $\mathrm{EPLA}_{2}$ activation has been demonstrated in rat hippocampal slices, where it could be blocked by a specific $\mathrm{CPLA}_{2}$ inhibitor and was accompanied by the formation of lyso-phosphatidylcholine and glycerophosphocholine, consistent with activation of the AA-selective $\mathrm{CPLA}_{2}$ (Dennis, 1994; Weichel et al, 1999). Other studies also reported that $\mathrm{Ca}^{2+}$-mediated activation of $\mathrm{PLA}_{2}$ in neurons released AA following NMDA (Dumuis et al, 1988; Lazarewicz et al, 1990; Pellerin and Wolfe, 1991; Tapia-Arancibia et al, 1992). Although both $\mathrm{CPLA}_{2}$ and sPLA $\mathrm{S}_{2}$ were activated in some of those studies (Kim et al, 1995), it is likely that mainly cPLA was activated in ours, as CPLA ${ }_{2}$ is sensitive to the low $\mathrm{Ca}^{2+}$ concentrations, $300 \mathrm{nM}$ to $1 \mu \mathrm{M}$ (Clark et al, 1995; Ismailov et al, 2004) that occur during normal neuronal activation. sPLA $A_{2}$ activation requires a much higher $\mathrm{Ca}^{2+}$ concentration, $16-18 \mathrm{mM}$, and is involved mainly in the presynaptic release of synaptic vesicles (Dennis, 1994; Matsuzawa et al, 1996; Wei et al, 2003). iPLA 2 is $\mathrm{Ca}^{2+}$-independent and selective for DHA acid rather than AA (Dennis, 1994; Strokin et al, 2004).

The chronic LiCl diet of this study is reported to reduce global brain mRNA, protein and activity levels of $\mathrm{CPLA}_{2}$ in rats, but not to affect expression of sPLA ${ }_{2}$ or iPLA (Bosetti $_{2}$ et al, 2002a, b; Chang and Jones, 1998; Rapoport and Bosetti,
2002; Rintala et al, 1999; Weerasinghe et al, 2004). Its $\mathrm{CPLA}_{2}$ effect may be due a lithium-induced downregulation of $\mathrm{Ca}^{2}$ ${ }^{+}$-dependent PKC, to reduce expression of PKC-dependent AP-2, which regulates $\mathrm{CPLA}_{2}$ transcription (Rao et al, 2005; Wang et al, 2001). Consistent with selective cPLA ${ }_{2}$ targeting, the $\mathrm{LiCl}$ diet reduces incorporation and turnover rates of AA but not of DHA in brain phospholipids of unanesthetized rats (Chang et al, 1996). Thus, one explanation for its suppression of the NMDA-induced increments in $k^{\star}$ for AA in the present study is that it directly reduces the $\mathrm{CPLA}_{2}$ activation response to increased intracellular $\mathrm{Ca}^{2+}$.

Another possible explanation is that it changed the phosphorylation state of NMDAR subunits, preventing NMDAR-mediated $\mathrm{Ca}^{2+}$ entry into cells. For example, exposing cultured neurons to lithium, or injecting lithium into rats for 7 days, has been reported to reduce NMDARmediated $\mathrm{Ca}^{2+}$ influx by inhibiting NR2B tyrosine phosphorylation and Src tyrosine kinase (Hashimoto et al, 2002, 2003; Nonaka and Chuang, 1998), or by reducing NR2A tyrosine phosphorylation and interactions of the NR2A subunit with Src and Fyn mediated by PSD-95 in the rat hippocampus (Ma and Zhang, 2003; Ma et al, 2004). If blocking NMDAR-mediated $\mathrm{Ca}^{2+}$ entry into neurons were the primary reason for the reduced $k^{*}$ responses, then lithium's reduction of global $\mathrm{CPLA}_{2}$ expression in the rat 
Table 3 Mean Values of Arachidonic Acid Incorporation Coefficients $k^{* a}$ in Lithium Diet-Fed Rats, at Baseline (in Response to Saline) and in Response to NMDA ${ }^{b}$

$\mathrm{LiCl}$ diet

\section{Brain region}

Telencephalon

Prefrontal cortex (10)-I

Prefrontal cortex (I0)-IV

Primary olfactory cortex

Frontal cortex (10)

Layer I

Layer IV

Frontal cortex (8)

Layer I

Layer IV

Pyriform cortex

Anterior cingulate cortex

Motor cortex

Layer I

Layer II-III

Layer IV

Layer $\mathrm{V}$

Layer VI

Somatosensory cortex

Layer I

Layer II-III

Layer IV

Layer $\mathrm{V}$

Layer VI

Auditory cortex

Layer I
Layer IV
Layer VI

Visual cortex

Layer I
Layer IV
Layer VI

Preoptic area (LPO/MPO)

Suprachiasmatic nu

Globus pallidus

Bed nu stria terminalis

Olfactory tubercle

Diagonal band

$$
\begin{aligned}
& \text { Dorsal } \\
& \text { Ventral }
\end{aligned}
$$

Amygdala basolat/med
$6.09 \pm 0.97$

$6.88 \pm 1.00$

$4.62 \pm 0.68$

$7.05 \pm 1.12$

$6.12 \pm 0.87$

$6.15 \pm 0.88$

$6.54 \pm 0.86$

$4.92 \pm 0.81$

$4.82 \pm 0.67$

$6.09 \pm 0.8$

$6.06 \pm 0.97$

$6.83 \pm 1.06$

$5.86 \pm 1.03$

$5.84 \pm 1.06$

$6.36 \pm 0.84$

$7.20 \pm 0.55$

$6.29 \pm 0.63$

$7.53 \pm 0.94$

$8.78 \pm 1.10$

$7.27 \pm 0.91$

$6.66 \pm 0.83$

$6.79 \pm 0.85$

$6.42 \pm 0.87$

$6.95 \pm 0.93$

$5.16 \pm 0.76$

$5.05 \pm 0.67$

$4.68 \pm 0.67$

$4.86 \pm 0.83$

$5.47 \pm 0.68$

$5.52 \pm 0.89$

$5.42 \pm 0.79$

$4.29 \pm 1.00$
$6.95 \pm 1.60$

$8.10 \pm 1.52$

$7.00 \pm 1.17$

$5.12 \pm 0.64$

$5.24 \pm 0.47$

$5.96 \pm 1.08$

$5.06 \pm 0.80$

$5.02 \pm 1.31$

$6.82 \pm 0.49$

$6.78 \pm 0.77$

$6.45 \pm 0.73$

$4.48 \pm 1.2$

$4.54 \pm 1.0$

$4.00 \pm 0.77$

$4.37 \pm 1.04$

$5.5 \mathrm{I} \pm 0.72$

5. $10 \pm 0.95$

$5.35 \pm 1.30$

$5.02 \pm 0.72$
$4.88+0.89$

$5.66 \pm 0.48$

$5.62 \pm 0.91$

$5.40 \pm 0.90$

$4.54 \pm 0.43$
$<0.00$ I

$<0.00$ I

$<0.00$ I

$<0.001$

$<0.00$ I

0.002

$<0.00$ I

$<0.00$ I

0.001

$<0.00$ I

0.002

$<0.00$ I

0.001

$<0.00$ I

NS

NS

0.005

NS

NS

0.002

NS

NS

0.015

NS

NS

0.010

0.001

NS

NS

0.029

NS

NS

0.003

NS

NS

NS
0.009

$<0.00$ ।

NS

0.016

NS

0.003

0.010

0.003

NS

0.001

NS
NS

0.003

NS

0.008

0.014

NS

0.002 
Table 3 Continued

LiCl diet

\section{Brain region}

Hippocampus

CAI

CA2

CA3

Dentate gyrus

SLM

Accumbens nucleus

Caudate putamen

Dorsal

Ventral

Lateral

Medial

Septal nucleus lateral

Medial

Diencephalon

Habenular nu lateral

Medial

Lat geniculate nu dorsal

Geniculate medial

Thalamus

Ventroposterior lat nu

Ventroposterior med nu

Paratenial nu

Anteroventral nu

Anteromedial nu

Reticular nu

Paraventricular nu

Parafascicular nu

Subthalamic nucleus

Hypothalamus

Supraoptic nu

Lateral

Anterior

Periventricular

Arcuate

Ventromedial

Posterior

Mammillary nucleus

Mesencephalon

Interpeduncular nucleus

Substantia nigra

$$
\text { Pars reticulata }
$$

Pars compacta

Pretectal area
$4.22 \pm 0.66$

$4.48 \pm 0.61$

$4.67 \pm 0.63$

$5.22 \pm 0.89$

$6.47 \pm 0.52$

$5.33 \pm 1.06$

$5.49 \pm 0.95$

$5.57 \pm 1.00$

$5.48 \pm 0.88$

$5.41 \pm 0.85$

$4.90 \pm 0.57$

$5.06 \pm 1.09$
$4.20 \pm 0.35$

$5.74 \pm 0.70$

$5.13+0.5 \mid$

$9.08 \pm 1.12$

$5.72 \pm 0.51$

$5.65 \pm 0.75$

$6.88 \pm 0.71$
$4.5 I \pm 0.29$

$4.7 \mid \pm 0.39$

$5.14 \pm 0.66$

$5.69 \pm 0.48$

$5.87 \pm 1.03$

$5.89 \pm 0.72$

$5.87 \pm 0.74$

$5.84 \pm 0.79$

$5.80 \pm 0.74$

$4.90 \pm 0.88$

$4.81 \pm 1.05$

$8.22 \pm 0.74$

$8.30 \pm 0.72$

$6.82 \pm 0.55$

$6.90 \pm 0.54$

$5.95 \pm 0.46$

$.95 \pm 0.46$

$6.30 \pm 0.73$

$8.66 \pm 0.90$

$6.48+0.80$

$6.54+1.10$

$6.76 \pm 0.34$

$5.38 \pm 0.42$

$5.94 \pm 0.63$

$4.16 \pm 0.63$

$4.90 \pm 0.66$

$5.03 \pm 0.47$

$4.19 \pm 0.46$

$5.85 \pm 1.13$

$5.48 \pm 1.09$

$5.03 \pm 0.56$

$4.25 \pm 0.55$
$4.59 \pm 0.65$
$4.80 \pm 0.66$
$5.42 \pm 1.02$
$5.65 \pm 0.37$
$5.70 \pm 1.21$

$5.11 \pm 0.94$

$5.28 \pm 1.00$

$5.15 \pm 1.13$

$5.13 \pm 1.15$

$4.05 \pm .84$

$4.95 \pm 0.87$

$8.09 \pm 0.54$

$7.93 \pm 0.60$

$7.01 \pm 0.47$

$6.97 \pm 36$

$5.98 \pm 0.91$

$6.20 \pm 0.7 \mid$

$6.36+0.92$

$7.60+1.15$

$5.80+1.38$

$5.87 \pm 1.17$

$6.58 \pm 1.03$

$5.98 \pm 0.51$

$6.36 \pm 1.03$

$4.29 \pm 1.10$

$4.41 \pm 0.85$

$4.33 \pm 0.82$

$3.85 \pm 0.67$

$4.79 \pm 0.82$

$4.35 \pm 0.86$

$5.61 \pm 0.54$

$6.64 \pm 0.88$

$10.09 \pm 1.19$

$5.19 \pm 0.58$

$5.39 \pm 0.44$

$6.06 \pm 0.67$
$9.98 \pm 0.51$

$5.61+0.54$

$5.48 \pm 0.60$

$6.45 \pm 0.70$
$<0.000$ I

0.001

0.025

0.033

NS

NS

0.003

0.006

NS

$<0.000$ ।

$<0.000$ ।

0.001

NS

0.003

NS

NS

0.027

0.032

NS

0.013

NS

NS

NS

NS

0.012

NS

0.002

$<0.000$ ।

NS

0.002

NS

$<0.000$ ।

0.038

0.011

NS

0.003

$<0.000$ ।

NS

NS

NS

NS

NS

NS

0.02 
Table 3 Continued

$\mathrm{LiCl}$ diet

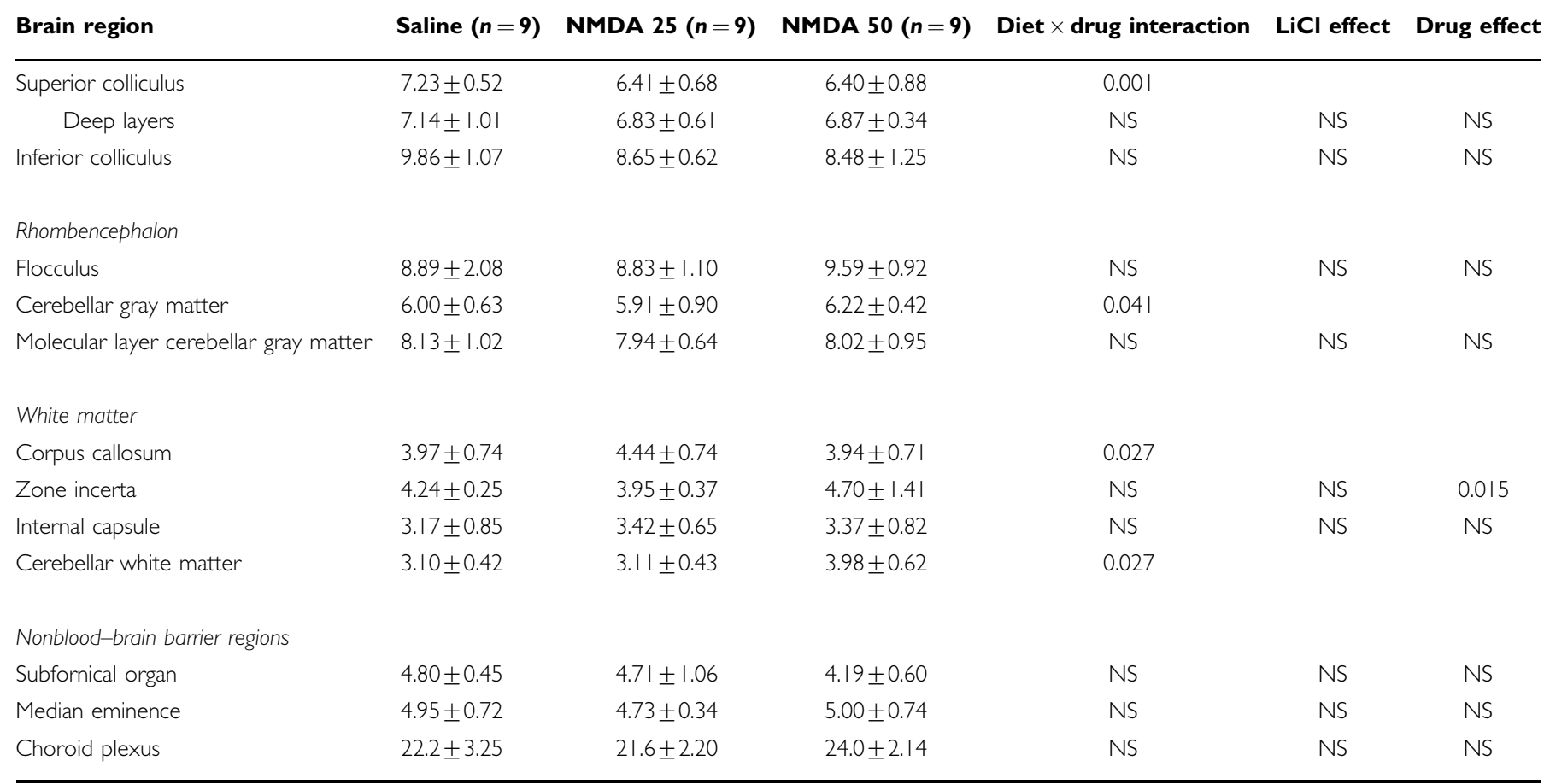

nu, nucleus; lat, lateral; med, medial; SLM, stratum lacunosum-molecular of the hippocampus.

Each value is a mean \pm SD.

NS: not significant.

In cases of statistically significant Diet $\times$ Drug interaction, unpaired t tests were realized. $* p<0.05 ; * *$ * $<0.0$ I; *** $p<0.00$ I, LiCl diet-saline vs control diet-saline. No mean $k^{*}$ in response to 25 or $50 \mathrm{mg} / \mathrm{kg}$ NMDA in the LiCl-fed rats differed significantly from $k^{*}$ in response to saline.

${ }^{\mathrm{a}} \mathrm{k}^{*}=(\mathrm{ml} / \mathrm{s} / \mathrm{g}) \times 10^{-4}$.

bNMDA administration: 25 and $50 \mathrm{mg} / \mathrm{kg}$ i.p., $10 \mathrm{~min}$.

brain (see above) could be secondary to a chronic downregulation of $\mathrm{Ca}^{2+}$ entry via defective NMDARs (Du et al, 2004; Gray et al, 2003; Karkanias and Papke, 1999). In any case, blocking NMDAR signaling via $\mathrm{CPLA}_{2}$ as contributing to lithium's therapeutic efficacy is consistent with evidence that other anti-BD drugs (Calabrese et al, 1995) - lamotrigine (Farber et al, 2002; McIntyre et al, 2004), carbamazepine (Hough et al, 1996; Kubota et al, 1994), and valproic acid (Zeise et al, 1991) have direct or indirect NMDARblocking properties.

Reduced NMDAR signaling as contributing to lithium's efficacy is consistent with evidence of disturbed NMDAR subunit expression in the BD brain. NR1 and NR2 genes are reported to confer susceptibility to BD (Itokawa et al, 2003; Mundo et al, 2003), and NMDAR density is decreased in the post-mortem BD hippocampus (Scarr et al, 2003). In other studies, NR2D mRNA was higher in the post-mortem BD striatum (Meador-Woodruff et al, 2001), NR1 mRNA was decreased in the $\mathrm{BD}$ dentate gyrus and $\mathrm{CA} 3$ of the hippocampus (Law and Deakin, 2001), and NR3A mRNA was decreased in the $\mathrm{BD}$ prefrontal cortex (Mueller and Meador-Woodruff, 2004).

It remains possible that the NMDA response involved neuroreceptors other than NMDA. For example, dopaminergic and glutamatergic/NMDA transmission are closely linked in the mammalian brain, particularly in the prefrontal cortex, striatum, and nucleus accumbens (Ferretti et al, 2005; Ikeda et al, 2003; Piomelli and Di Marzo, 1993; Rogue et al, 1990; Takeuchi et al, 2002; Tseng and O'Donnell, 2004; Wang et al, 2003). Medium-sized spiny neurons, the majority of neurons in the neostriatum, receive convergent glutamate-containing afferents from the neocortex and dopamine-containing afferents from the substantia nigra and ventral tegmentum (Murata et al, 2002). Dopamine receptor-linked signaling can affect the phosphorylation state and synaptic efficacy of NMDARs coexpressed on striatal neurons (Cepeda and Levine, 1998; Chase, 2004; Nair et al, 1998), whereas inhibition of NMDAR expression by antisense oligonucleotides can modulate pre- and postsynaptic expression of $\mathrm{D}_{2}$-like receptors in these neurons (Murata et al, 2002). Furthermore, both dopaminergic and glutamatergic pathways can modulate neuroplasticity involving cAMP, DARPP-32 (dopamine, cAMP-regulated phosphoprotein of $32 \mathrm{kDa}$ ), and ERK (extracellular signal-regulated kinase) (Gould and Manji, 2005; Valjent et al, 2005). In this regard, chronic lithium increased the level of DARPP-32 in the rat frontal cortex (Guitart and Nestler, 1992), which may explain its ability to activate the ERK-signaling cascade (Einat et al, 2003). 
In view of the interplay between $\mathrm{D}_{2}$-like receptors and NMDARs, it is not surprising that chronic $\mathrm{LiCl}$ suppresses increments in $k^{*}$ for $\mathrm{AA}$ in unanesthetized rats given quinpirole (Basselin et al, 2005a), an agonist of $\mathrm{D}_{2}$-like receptors coupled to $\mathrm{PLA}_{2}$ via a G-protein (Bhattacharjee et al, 2005; Hayakawa et al, 2001; Huo and Healy, 1991; Vial and Piomelli, 1995). This suppression agrees with evidence that drugs that interfere with dopaminergic neurotransmission can be effective in BD (Bunney and Garland-Bunney, 1987; Bymaster and Felder, 2002; Fisher et al, 1991; Peet and Peters, 1995; Post et al, 1980; Sultzer and Cummings, 1989). On the other hand, the ability of chronic LiCl to potentiate $k^{\star}$ responses in rats to the muscarinic $\mathrm{M}_{1,3,5}$ receptor agonist, arecoline (Basselin et al, 2003), is consistent with reports that cholinomimetics can be therapeutic as well (Bunney and Garland-Bunney, 1987; Bymaster and Felder, 2002). These published data, and the data of this study, suggest that lithium acts in BD by rectifying several neurotransmitter-signaling imbalances through downregulating NMDAR and $\mathrm{D}_{2}$-like receptor signaling and upregulating $M_{1,3,5}$ receptor signaling involving $\mathrm{PLA}_{2}$ and the AA cascade (Bunney and Garland-Bunney, 1987; Bymaster and Felder, 2002; Dumuis et al, 1988; Rapoport and Bosetti, 2002; Shimizu and Wolfe, 1990).

Glutamate at excessive concentrations can kill neurons by the process of excitotoxicity (Coyle and Puttfarcken, 1993; Rothman and Olney, 1995), and it has been suggested that glutamatergic excitotoxicity contributes to $\mathrm{BD}$ (Zarate et al, 2003). Lithium's ability to block NMDA-initiated increments in $k^{*}$ for $\mathrm{AA}$ (this paper) is consistent with evidence that chronic lithium can be neuroprotective in animal models of neurodegeneration and even in BD patients (Moore et al, 2000; Rowe and Chuang, 2004; Zarate et al, 2003). Excess $\mathrm{PLA}_{2}$-mediated release of AA, with concurrent formation of excess lyso-phospholipids, can engender neurotoxic sequellae (Bazan et al, 1995; Farooqui et al, 1997; Sapirstein and Bonventre, 2000).

Finally, interference in the normal NMDAR-initiated $\mathrm{PLA}_{2}$-mediated release of $\mathrm{AA}$ by lithium may disturb long-term potentiation in the hippocampus, considered the basis of learning and memory (Dumuis et al, 1988; Nishizaki et al, 1999; Otmakhov et al, 2004; Schmitt et al, 2005; Williams et al, 1989). This may be relevant to reports that lithium treatment inhibited learning, memory, and speed of information processing in BD patients and to some extent in control subjects (Honig et al, 1999; Pachet and Wisniewski, 2003; Stip et al, 2000).

\section{REFERENCES}

Axelrod J (1995). Phospholipase $\mathrm{A}_{2}$ and $\mathrm{G}$ proteins. Trends Neurosci 18: 64-65.

Barchas J, Hamblin M, Malenka R (1994). Biochemical hypotheses of mood and anxiety disorders. In: Siegel GJ, Agranoff BW, Albers RW, Molinoff PB (eds). Basic Neurochemistry, 5th edn. Raven Press: New York. pp 979-1001.

Basavarajappa BS, Cooper TB, Hungund BL (1998). Effect of chronic ethanol exposure on mouse brain arachidonic acid specific phospholipase $A_{2}$. Biochem Pharmacol 55: 515-521.

Basselin M, Chang L, Bell J, Rapoport SI (2005a). Chronic lithium chloride administration to unanesthetized rats attenuates brain dopamine D2-like receptor initiated signaling via arachidonic acid. Neuropsychopharmacology 30: 1064-1075.
Basselin M, Chang L, Seemann R, Bell JM, Rapoport SI (2003). Chronic lithium administration potentiates brain arachidonic acid signaling at rest and during cholinergic activation in awake rats. J Neurochem 85: 1553-1562.

Basselin M, Chang L, Seemann R, Bell JM, Rapoport SI (2004). Lithium treatment of rats may reduce brain NMDA-initiated arachidonic acid signaling by downregulating $\mathrm{Ca}^{2+}$-dependent cytosolic phospholipase $\mathrm{A}_{2}$. Neuropsychopharmacology 29 (Suppl 1): S181.

Basselin M, Chang L, Seemann R, Bell JM, Rapoport SI (2005b). Chronic lithium administration to rats selectively modifies $5-\mathrm{HT}_{2 \mathrm{~A} / 2 \mathrm{C}}$ receptor-mediated brain signaling via arachidonic acid. Neuropsychopharmacology 30: 461-472.

Bauer M, Alda M, Priller J, Young LT (2003). Implications of the neuroprotective effects of lithium for the treatment of bipolar and neurodegenerative disorders. Pharmacopsychiatry 36(Suppl 3): S250-S254.

Bayon Y, Hernandez M, Alonso A, Nunez L, Garcia-Sancho J, Leslie C et al (1997). Cytosolic phospholipase $A_{2}$ is coupled to muscarinic receptors in the human astrocytoma cell line $1321 \mathrm{~N} 1$ : characterization of the transducing mechanism. Biochem J 323: 281-287.

Bazan NG, Rodriguez de Turco EB, Allan G (1995). Mediators of injury in neurotrauma: intracellular signal transduction and gene expression. J Neurotrauma 12: 791-814.

Bernard V, Bolam JP (1998). Subcellular and subsynaptic distribution of the NR1 subunit of the NMDA receptor in the neostriatum and globus pallidus of the rat: co-localization at synapses with the GluR2/3 subunit of the AMPA receptor. Eur J Neurosci 10: 3721-3736.

Bhattacharjee AK, Chang L, Lee HJ, Bazinet RP, Seemann R, Rapoport SI (2005). $\mathrm{D}_{2}$ but not $\mathrm{D}_{1}$ dopamine receptor stimulation augments brain signaling involving arachidonic acid in unanesthetized rats. Psychopharmacology (Berlin) 180: 735-742.

Bland M (2000). An Introduction to Medical Statistics, 3rd edn. Oxford University Press: Oxford.

Bosetti F, Rintala J, Seemann R, Rosenberger TA, Contreras MA, Rapoport SI et al (2002a). Chronic lithium downregulates cyclooxygenase- 2 activity and prostaglandin $\mathrm{E}_{2}$ concentration in rat brain. Mol Psychiatr 7: 844-850.

Bosetti F, Seemann R, Bell JM, Zahorchak R, Friedman E, Rapoport SI et al (2002b). Analysis of gene expression with cDNA microarrays in rat brain after 7 and 42 days of oral lithium administration. Brain Res Bull 57: 205-209.

Braitenberg V, Schüz A (1998). Cortex: Statistics and Geometry of Neuronal Connectivity. Springer: Berlin.

Brodal A (1981). Neurological Anatomy in Relation to Clinical Medicine 3rd edn Oxford University Press: Oxford.

Browne SE, Muir JL, Robbins TW, Page KJ, Everitt BJ, McCulloch J (1998). The cerebral metabolic effects of manipulating glutamatergic systems within the basal forebrain in conscious rats. Eur $J$ Neurosci 10: 649-663.

Bunney WEJ, Garland-Bunney BL (1987). Mechanisms of action of lithium in affective illness: Basic and clinical implications. In: Meltzer HY (ed). Psychopharmacology: The Third Generation of Progress. Raven: New York. pp 553-565.

Bymaster FP, Felder CC (2002). Role of the cholinergic muscarinic system in bipolar disorder and related mechanism of action of antipsychotic agents. Mol Psychiatr 7(Suppl 1): S57-S63.

Cade JF (1999). John Frederick Joseph Cade: Family memories on the occasion of the 50th anniversary of his discovery of the use of lithium in mania. 1949. Aust NZ J Psychiatr 33: 615-622.

Calabrese JR, Bowden C, Woyshville MJ (1995). Lithium and the anticonvulsants in the treatment of bipolar disorder. In: Bloom FE, Kupfer DJ (eds). Psychopharmacology: The Fourth Generation of Progress. Raven: New York. pp 1099-1111. 
Cepeda C, Levine MS (1998). Dopamine and N-methyl-D-aspartate receptor interactions in the neostriatum. Dev Neurosci 20: 1-18. Chang MC, Bell JM, Purdon AD, Chikhale EG, Grange E (1999). Dynamics of docosahexaenoic acid metabolism in the central nervous system: lack of effect of chronic lithium treatment. Neurochem Res 24: 399-406.

Chang MC, Jones CR (1998). Chronic lithium treatment decreases brain phospholipase $A_{2}$ activity. Neurochem Res 23: 887-892.

Chang MCJ, Arai T, Freed LM, Wakabayashi S, Channing MA, Dunn BB et al (1997). Brain incorporation of $\left[1-{ }^{11} \mathrm{C}\right]$-arachidonate in normocapnic and hypercapnic monkeys, measured with positron emission tomography. Brain Res 755: 74-83.

Chang MCJ, Grange E, Rabin O, Bell JM, Allen DD, Rapoport SI (1996). Lithium decreases turnover of arachidonate in several brain phospholipids. Neurosci Lett 220: 171-174.

Chase TN (2004). Striatal plasticity and extrapyramidal motor dysfunction. Parkinsonism Relat Disord 10: 305-313.

Clark JD, Schievella AR, Nalefski EA, Lin LL (1995). Cytosolic phospholipase $\mathrm{A}_{2}$. J Lipid Mediat Cell Signal 12: 83-117.

Colbran RJ (2004). Targeting of calcium/calmodulin-dependent protein kinase II. Biochem J 378: 1-16.

Coyle JT, Puttfarcken P (1993). Oxidative stress, glutamate, and neurodegenerative disorders. Science 262: 689-695.

Dai H, Gebhardt K, Carey RJ (1995). Time course effects of MK801: the relationship between brain neurochemistry and behavior. Brain Res Bull 36: 175-180.

DeGeorge JJ, Nariai T, Yamazaki S, Williams WM, Rapoport SI (1991). Arecoline-stimulated brain incorporation of intravenously administered fatty acids in unanesthetized rats. $J$ Neurochem 56: 352-355.

DeGeorge JJ, Noronha JG, Bell J, Robinson P, Rapoport SI (1989). Intravenous injection of $\left[1-{ }^{14} \mathrm{C}\right]$ arachidonate to examine regional brain lipid metabolism in unanesthetized rats. J Neurosci Res 24: 413-423.

DeMar Jr JC, Ma K, Bell JM, Rapoport SI (2004a). Half-lives of docosahexaenoic acid in rat brain phospholipids are prolonged by 15 weeks of nutritional deprivation of n-3 polyunsaturated fatty acids. J Neurochem 91: 1125-1137.

DeMar JC, Ma K, Bell J, Rapoport SI (2004b). Brain conversion of linoleic to arachidonic acid is not a major source of the arachidonate found in brain phospholipids of adult rats. Abstr. International Workshop on Brain Uptake and Utilization of Fatty Acids, Lipids \& Lipoproteins, October 7-9, 2004, Bethesda, MD.

Dennis EA (1994). Diversity of group types, regulation, and function of phospholipase $A_{2}$. J Biol Chem 269: 13057-13060.

Du J, Gray NA, Falke CA, Chen W, Yuan P, Szabo ST et al (2004). Modulation of synaptic plasticity by antimanic agents: the role of AMPA glutamate receptor subunit 1 synaptic expression. J Neurosci 24: 6578-6589.

Dumuis A, Sebben M, Haynes L, Pin JP, Bockaert J (1988). NMDA receptors activate the arachidonic acid cascade system in striatal neurons. Nature 336: 68-70.

Einat H, Manji HK, Gould TD, Du J, Chen G (2003). Possible involvement of the ERK signaling cascade in bipolar disorder: behavioral leads from the study of mutant mice. Drug News Perspect 16: 453-463.

Farber NB, Jiang XP, Heinkel C, Nemmers B (2002). Antiepileptic drugs and agents that inhibit voltage-gated sodium channels prevent NMDA antagonist neurotoxicity. Mol Psychiatr 7: 726-733.

Farooqui AA, Yang HC, Horrocks L (1997). Involvement of phospholipase $\mathrm{A}_{2}$ in neurodegeneration. Neurochem Int 30: 517-522.

Feinberg I, Campbell IG, Marrs JC (1995). Intraperitoneal dizocilpine induces cortical spike-wave seizure discharges in rats. Neurosci Lett 196: 157-160.

Felder CC, Dieter P, Kinsella J, Tamura K, Kanterman RY, Axelrod J (1990). A transfected m5 muscarinic acetylcholine receptor stimulates phospholipase $\mathrm{A}_{2}$ by inducing both calcium influx and activation of protein kinase C. J Pharmacol Exp Ther 255: $1140-1147$.

Fenwick PB, Robertson R (1983). Changes in the visual evoked potential to pattern reversal with lithium medication. Electroencephalogr Clin Neurophysiol 55: 538-545.

Ferretti V, Florian C, Costantini VJ, Roullet P, Rinaldi A, De Leonibus $\mathrm{E}$ et al (2005). Co-activation of glutamate and dopamine receptors within the nucleus accumbens is required for spatial memory consolidation in mice. Psychopharmacology (Berlin) 179: 108-116.

Fisher G, Pelonero AL, Ferguson C (1991). Mania precipitated by prednisone and bromocriptine. Gen Hosp Psychiatr 13: 345-346.

Folch J, Lees M, Sloane Stanley GH (1957). A simple method for the isolation and purification of total lipides from animal tissues. J Biol Chem 226: 497-509.

Fonnum F (1984). Glutamate: a neurotransmitter in mammalian brain. J Neurochem 42: 1-11.

Fukunaga K, Soderling TR, Miyamoto E (1992). Activation of $\mathrm{Ca}^{2+}$ / calmodulin-dependent protein kinase II and protein kinase $\mathrm{C}$ by glutamate in cultured rat hippocampal neurons. J Biol Chem 267: 22527-22533.

Gould TD, Manji HK (2005). DARPP-32: a molecular switch at the nexus of reward pathway plasticity. Proc Natl Acad Sci USA 102: 253-254.

Gray NA, Du J, Falke CS, Yuan P, Manji HK (2003). Lithium regulates total and synaptic expression of the AMPA glutamate receptor GluR2 in vitro and in vivo. Ann NY Acad Sci 1003: 402-404.

Guitart X, Nestler EJ (1992). Chronic administration of lithium or other antidepressants increases levels of DARPP-32 in rat frontal cortex. J Neurochem 59: 1164-1167.

Gurd JW, Bissoon N (1997). The N-methyl-D-aspartate receptor subunits NR2A and NR2B bind to the SH2 domains of phospholipase C-gamma. J Neurochem 69: 623-630.

Hashimoto R, Fujimaki K, Jeong MR, Christ L, Chuang D (2003). Lithium-induced inhibition of Src tyrosine kinase in rat cerebral cortical neurons: a role in neuroprotection against $N$-methylD-aspartate receptor-mediated excitotoxicity. FEBS Lett 538: 145-148.

Hashimoto R, Hough C, Nakazawa T, Yamamoto T, Chuang DM (2002). Lithium protection against glutamate excitotoxicity in rat cerebral cortical neurons: involvement of NMDA receptor inhibition possibly by decreasing NR2B tyrosine phosphorylation. J Neurochem 80: 589-597.

Hayakawa T, Chang MC, Rapoport SI, Appel NM (2001). Selective dopamine receptor stimulation differentially affects $[3 \mathrm{H}]$ arachidonic acid incorporation, a surrogate marker for phospholipase $\mathrm{A}_{2}$-mediated neurotransmitter signal transduction, in a rodent model of Parkinson's disease. J Pharmacol Exp Ther 296: 1074-1084.

Hegerl U, Herrmann WM, Ulrich G, Muller-Oerlinghausen B (1990). Effects of lithium on auditory evoked potentials in healthy subjects. Biol Psychiatr 27: 555-560.

Holman RT (1986). Control of polyunsaturated acids in tissue lipids. J Am Coll Nutr 5: 183-211.

Honig A, Arts BM, Ponds RW, Riedel WJ (1999). Lithium induced cognitive side-effects in bipolar disorder: a qualitative analysis and implications for daily practice. Int Clin Psychopharmacol 14: 167-171.

Hough CJ, Irwin RP, Gao XM, Rogawski MA, Chuang DM (1996). Carbamazepine inhibition of $\mathrm{N}$-methyl-D-aspartate-evoked calcium influx in rat cerebellar granule cells. J Pharmacol Exp Ther 276: 143-149.

Huo TL, Healy DP (1991). Prostaglandin $E_{2}$ production in rat IMCD cells. I. Stimulation by dopamine. Am J Physiol 261: F647-F654.

Ikeda H, Akiyama G, Fujii Y, Minowa R, Koshikawa N, Cools AR (2003). Role of AMPA and NMDA receptors in the nucleus 
accumbens shell in turning behaviour of rats: interaction with dopamine receptors. Neuropharmacology 44: 81-87.

Ismailov I, Kalikulov D, Inoue T, Friedlander MJ (2004). The kinetic profile of intracellular calcium predicts long-term potentiation and long-term depression. J Neurosci 24: 98479861.

Itokawa M, Yamada K, Iwayama-Shigeno Y, Ishitsuka Y, DeteraWadleigh S, Yoshikawa T (2003). Genetic analysis of a functional GRIN2A promoter (GT)n repeat in bipolar disorder pedigrees in humans. Neurosci Lett 345: 53-56.

Jarvis MF, Murphy DE, Williams M (1987). Quantitative autoradiographic localization of NMDA receptors in rat brain using $[3 \mathrm{H}] \mathrm{CPP}:$ comparison with $[3 \mathrm{H}] \mathrm{TCP}$ binding sites. Eur $J$ Pharmacol 141: 149-152.

Karkanias NB, Papke RL (1999). Subtype-specific effects of lithium on glutamate receptor function. J Neurophysiol 81: 1506-1512.

Kim DK, Rordorf G, Nemenoff RA, Koroshetz WJ, Bonventre JV (1995). Glutamate stably enhances the activity of two cytosolic forms of phospholipase $\mathrm{A}_{2}$ in brain cortical cultures. Biochem $J$ 310(Part 1): 83-90.

Kishimoto K, Matsumura K, Kataoka Y, Morii H, Watanabe Y (1999). Localization of cytosolic phospholipase $A_{2}$ messenger RNA mainly in neurons in the rat brain. Neuroscience 92: 1061-1077.

Kolko M, Bruhn T, Christensen T, Lazdunski M, Lambeau G, Bazan NG et al (1999). Secretory phospholipase $A_{2}$ potentiates glutamate-induced rat striatal neuronal cell death in vivo. Neurosci Lett 274: 167-170.

Kolko M, Rodriguez de Turco EB, Diemer NH, Bazan NG (2003). Neuronal damage by secretory phospholipase $\mathrm{A}_{2}$ : modulation by cytosolic phospholipase $\mathrm{A}_{2}$, platelet-activating factor, and cyclooxygenase-2 in neuronal cells in culture. Neurosci Let 338: $164-168$.

Krystal JH, Sanacora G, Blumberg H, Anand A, Charney DS, Marek $\mathrm{G}$ et al (2002). Glutamate and GABA systems as targets for novel antidepressant and mood-stabilizing treatments. Mol Psychiatry 7(Suppl 1): S71-80.

Kubota T, Jibiki I, Fukushima T, Kurokawa K, Yamaguchi N (1994). Carbamazepine-induced blockade of induction of longterm potentiation in the perforant path-dentate gyrus pathway in chronically prepared rabbits. Neurosci Lett 170: 171-174.

Law AJ, Deakin JF (2001). Asymmetrical reductions of hippocampal NMDAR1 glutamate receptor mRNA in the psychoses. NeuroReport 12: 2971-2974.

Lazarewicz JW, Wroblewski JT, Costa E (1990). N-methyl-Daspartate-sensitive glutamate receptors induce calcium-mediated arachidonic acid release in primary cultures of cerebellar granule cells. J Neurochem 55: 1875-1881.

Lewis SJ, Barres C, Jacob HJ, Ohta H, Brody MJ (1989). Cardiovascular effects of the $\mathrm{N}$-methyl-D-aspartate receptor antagonist MK-801 in conscious rats. Hypertension 13: 759-765.

Ma J, Zhang GY (2003). Lithium reduced $N$-methyl-D-aspartate receptor subunit $2 \mathrm{~A}$ tyrosine phosphorylation and its interactions with Src and Fyn mediated by PSD-95 in rat hippocampus following cerebral ischemia. Neurosci Lett 348: 185-189.

Ma J, Zhang GY, Liu Y, Yan JZ, Hao ZB (2004). Lithium suppressed Tyr-402 phosphorylation of proline-rich tyrosine kinase (Pyk2) and interactions of Pyk2 and PSD-95 with NR2A in rat hippocampus following cerebral ischemia. Neurosci Res 49: 357-362.

Mainen ZF, Malinow R, Svoboda K (1999). Synaptic calcium transients in single spines indicate that NMDA receptors are not saturated. Nature 399: 151-155.

Makrides M, Neumann MA, Byard RW, Simmer K, Gibson RA (1994). Fatty acid composition of brain, retina, and erythrocytes in breast- and formula-fed infants. Am J Clin Nutr 60: 189-194.

Matsuzawa A, Murakami M, Atsumi G, Imai K, Prados P, Inoue K et al (1996). Release of secretory phospholipase $A_{2}$ from rat neuronal cells and its possible function in the regulation of catecholamine secretion. Biochem J 318(Part 2): 701-709.

McIntyre RS, Mancini DA, Lin P, Jordan J (2004). Treating bipolar disorder. Evidence-based guidelines for family medicine. Can Fam Phys 50: 388-394.

Meador-Woodruff JH, Hogg Jr AJ, Smith RE (2001). Striatal ionotropic glutamate receptor expression in schizophrenia, bipolar disorder, and major depressive disorder. Brain Res Bull 55: 631-640.

Monaghan DT, Cotman CW (1986). Identification and properties of $N$-methyl-D-aspartate receptors in rat brain synaptic plasma membranes. Proc Natl Acad Sci USA 83: 7532-7536.

Moore GJ, Bebchuk JM, Wilds IB, Chen G, Menji HK (2000). Lithium-induced increase in human brain grey matter. Lancet 356: $1241-1242$.

Mueller HT, Meador-Woodruff JH (2004). NR3A NMDA receptor subunit mRNA expression in schizophrenia, depression and bipolar disorder. Schizophr Res 71: 361-370.

Mundo E, Tharmalingham S, Neves-Pereira M, Dalton EJ, Macciardi F, Parikh SV et al (2003). Evidence that the $\mathrm{N}$ methyl-D-aspartate subunit 1 receptor gene (GRIN1) confers susceptibility to bipolar disorder. Mol Psychiatr 8: 241-245.

Murata M, Suzuki M, Tanaka K, Tajiri K, Emori K, Kurachi M (2002). N-methyl-D-aspartate-R1 receptor antisense oligodeoxynucleotide modulates pre- and postsynaptic expression of $\mathrm{D}_{2}$ dopamine receptors in the rat. Neurosci Lett 335: 9-12.

Nair VD, Savelli JE, Mishra RK (1998). Modulation of dopamine $\mathrm{D}_{2}$ receptor expression by an NMDA receptor antagonist in rat brain. J Mol Neurosci 11: 121-126.

Nishizaki T, Nomura T, Matsuoka T, Enikolopov G, Sumikawa K (1999). Arachidonic acid induces a long-lasting facilitation of hippocampal synaptic transmission by modulating PKC activity and nicotinic ACh receptors. Brain Res Mol Brain Res 69: 263-272.

Nonaka S, Chuang DM (1998). Neuroprotective effects of chronic lithium on focal cerebral ischemia in rats. NeuroReport 9: 2081-2084.

Ong WY, Sandhya TL, Horrocks LA, Farooqui AA (1999). Distribution of cytoplasmic phospholipase $A_{2}$ in the normal rat brain. J Hirnforsch 39: 391-400.

Ormandy GC, Song L, Jope RS (1991). Analysis of the convulsantpotentiating effects of lithium in rats. Exp Neurol 111: 356-361.

Otmakhov N, Tao-Cheng JH, Carpenter S, Asrican B, Dosemeci A, Reese TS et al (2004). Persistent accumulation of calcium/ calmodulin-dependent protein kinase II in dendritic spines after induction of NMDA receptor-dependent chemical long-term potentiation. J Neurosci 24: 9324-9331.

Pachet AK, Wisniewski AM (2003). The effects of lithium on cognition: an updated review. Psychopharmacology (Berlin) 170: 225-234.

Pal R, Eaton MJ, Islam S, Hake-Frendscho M, Kumar KN, Michaelis EK (1999). Immunocytochemical and in situ hybridization studies of the expression and distribution of three subunits of a complex with $N$-methyl-D-aspartate receptor-like properties. Neuroscience 94: 1291-1311.

Pardue S, Rapoport SI, Bosetti F (2003). Co-localization of cytosolic phospholipase $\mathrm{A}_{2}$ and cyclooxygenase-2 in Rhesus monkey cerebellum. Brain Res Mol Brain Res 116: 106-114.

Paxinos G, Watson C (1987). The Rat Brain in Stereotaxic Coordinates, 3rd edn. Academic Press: New York.

Peet M, Peters S (1995). Drug-induced mania. Drug Saf 12: 146-153.

Pellerin L, Wolfe LS (1991). Release of arachidonic acid by NMDAreceptor activation in the rat hippocampus. Neurochem Res 16: 983-989.

Petralia RS, Yokotani N, Wenthold RJ (1994). Light and electron microscope distribution of the NMDA receptor subunit NMDAR1 in the rat nervous system using a selective antipeptide antibody. J Neurosci 14: 667-696. 
Piomelli D, Di Marzo V (1993). Dopamine $D_{2}$ receptor signaling via the arachidonic acid cascade: modulation by cAMPdependent protein kinase $\mathrm{A}$ and prostaglandin $\mathrm{E}_{2}$. J Lipid Mediat 6: 433-443.

Post RM, Jimerson DC, Bunney Jr WE, Goodwin FK (1980). Dopamine and mania: behavioral and biochemical effects of the dopamine receptor blocker pimozide. Psychopharmacology (Berlin) 67: 297-305.

Qu Y, Chang L, Klaff J, Balbo A, Rapoport SI (2003). Imaging brain phospholipase $\mathrm{A}_{2}$ activation in awake rat in response to $5-\mathrm{HT}_{2 \mathrm{~A} /}$ $2 \mathrm{C}$ agonist (+/-)-2,5-dimethoxy-4-iodophenyl-2-aminopropane (DOI). Neuropsychopharmacology 28: 244-252.

Raichle ME, Gusnard DA (2002). Appraising the brain's energy budget. Proc Natl Acad Sci USA 99: 10237-10239.

Rao JS, Rapoport SI, Bosetti F (2005). Decrease in the AP-2 DNA binding activity and in the protein expression of AP-2alpha and AP-2beta in frontal cortex of rats treated with lithium for 6 weeks. Neuropsychopharmacology 30: 2006-2013.

Rapoport SI (2001). In vivo fatty acid incorporation into brain phospholipids in relation to plasma availability, signal transduction and membrane remodeling. J Mol Neurosci 16: 243-261.

Rapoport SI (2003). In vivo approaches to quantifying and imaging brain arachidonic and docosahexaenoic acid metabolism. $J$ Pediatr 143: S26-S34.

Rapoport SI, Bosetti F (2002). Do lithium and anticonvulsants target the brain arachidonic acid cascade in bipolar disorder? Arch Gen Psychiatr 59: 592-596.

Rintala J, Seemann R, Chandrasekaran K, Rosenberger TA, Chang L, Contreras MA et al (1999). $85 \mathrm{kDa}$ cytosolic phospholipase $\mathrm{A}_{2}$ is a target for chronic lithium in rat brain. NeuroReport 10: 3887-3890.

Robinson PJ, Noronha J, DeGeorge JJ, Freed LM, Nariai T, Rapoport SI (1992). A quantitative method for measuring regional in vivo fatty-acid incorporation into and turnover within brain phospholipids: Review and critical analysis. Brain Res Rev 17: 187-214.

Rogue P, Zwiller J, Malviya AN, Vincendon G (1990). Phosphorylation by protein kinase $C$ modulates agonist binding to striatal dopamine $\mathrm{D}_{2}$ receptors. Biochem Int 22: 575-582.

Rothman SM, Olney JW (1995). Excitotoxicity and the NMDA receptor - still lethal after eight years. Trends Neurosci 18: $57-58$.

Rowe MK, Chuang DM (2004). Lithium neuroprotection: molecular mechanisms and clinical implications. Expert Rev Mol Med 6: 1-18.

Sanfeliu C, Hunt A, Patel AJ (1990). Exposure to N-methyl-Daspartate increases release of arachidonic acid in primary cultures of rat hippocampal neurons and not in astrocytes. Brain Res 526: 241-248.

Sapirstein A, Bonventre JV (2000). Specific physiological roles of cytosolic phospholipase $\mathrm{A}_{2}$ as defined by gene knockouts. Biochim Biophys Acta 1488: 139-148.

Scarr E, Pavey G, Sundram S, MacKinnon A, Dean B (2003). Decreased hippocampal NMDA, but not kainate or AMPA receptors in bipolar disorder. Bipolar Disord 5: 257-264.

Schmitt JM, Guire ES, Saneyoshi T, Soderling TR (2005). Calmodulin-dependent kinase kinase/calmodulin kinase I activity gates extracellular-regulated kinase-dependent long-term potentiation. J Neurosci 25: 1281-1290.

Scott DB, Blanpied TA, Ehlers MD (2003). Coordinated PKA and PKC phosphorylation suppresses RXR-mediated ER retention and regulates the surface delivery of NMDA receptors. Neuropharmacology 45: 755-767.

Shibata S, Tominaga K, Hamada T, Watanabe S (1992). Excitatory effect of $N$-methyl-D-aspartate and kainate receptor on the 2deoxyglucose uptake in the rat suprachiasmatic nucleus in vitro. Neurosci Lett 139: 83-86.
Shimizu T, Wolfe LS (1990). Arachidonic acid cascade and signal transduction. J Neurochem 55: 1-15.

Sokoloff L (1999). Energetics of functional activation in neural tissues. Neurochem Res 24: 321-329.

Stewart CA, Reid IC (2002). Antidepressant mechanisms: functional and molecular correlates of excitatory amino acid neurotransmission. Mol Psychiatr 7(Suppl 1): S15-S22.

Stip E, Dufresne J, Lussier I, Yatham L (2000). A double-blind, placebo-controlled study of the effects of lithium on cognition in healthy subjects: mild and selective effects on learning. J Affect Disord 60: 147-157.

Strokin M, Sergeeva M, Reiser G (2004). Role of $\mathrm{Ca}^{2+}$-independent phospholipase $\mathrm{A}_{2}$ and n-3 polyunsaturated fatty acid docosahexaenoic acid in prostanoid production in brain: perspectives for protection in neuroinflammation. Int $J$ Dev Neurosci 22: 551-557.

Sultzer DL, Cummings JL (1989). Drug-induced mania - causative agents, clinical characteristics and management. A retrospective analysis of the literature. Med Toxicol Adverse Drug Exp 4: 127-143.

Tabachnick BG, Fidell LS (2001). Computer Assisted Research Design and Analysis. Allyn and Bacon: Boston, MA.

Takeuchi Y, Miyamoto E, Fukunaga K (2002). Activation of the rat dopamine $\mathrm{D}_{2}$ receptor promoter by mitogen-activated protein kinase and $\mathrm{Ca}^{2+} /$ calmodulin-dependent protein kinase II pathways. J Neurochem 83: 784-796.

Takita M, Yokoi H, Mizuno T (1997). NMDA receptor clustering in rat prefrontal cortex revealed by in vitro calcium macroimaging. NeuroReport 8: 551-553.

Tapia-Arancibia L, Rage F, Récasens M, Pin JP (1992). NMDA receptor activation stimulates phospholipase $\mathrm{A}_{2}$ and somatostatin release from rat cortical neurons in primary cultures. Eur $J$ Pharmacol 225: 253-262.

Tencé M, Cordier J, Premont J, Glowinski J (1994). Muscarinic cholinergic agonists stimulate arachidonic acid release from mouse striatal neurons in primary culture. J Pharmacol Exp Ther 269: 646-653.

Tseng KY, O’Donnell P (2004). Dopamine-glutamate interactions controlling prefrontal cortical pyramidal cell excitability involve multiple signaling mechanisms. J Neurosci 24: 5131-5139.

Ulrich G, Herrmann WM, Hegerl U, Muller-Oerlinghausen B (1990). Effect of lithium on the dynamics of electroencephalographic vigilance in healthy subjects. J Affect Disord 20: 19-25.

Valjent E, Pascoli V, Svenningsson P, Paul S, Enslen H, Corvol JC et al (2005). Regulation of a protein phosphatase cascade allows convergent dopamine and glutamate signals to activate ERK in the striatum. Proc Natl Acad Sci USA 102: 491-496.

Vial D, Piomelli D (1995). Dopamine $\mathrm{D}_{2}$ receptors potentiate arachidonate release via activation of cytosolic, arachidonicspecific phospholipase $A_{2}$. J Neurochem 64: 2765-2772.

Wang HY, Johnson GP, Friedman E (2001). Lithium treatment inhibits protein kinase $\mathrm{C}$ translocation in rat brain cortex. Psychopharmacology (Berlin) 158: 80-86.

Wang X, Zhong P, Gu Z, Yan Z (2003). Regulation of NMDA receptors by dopamine $\mathrm{D}_{4}$ signaling in prefrontal cortex. I Neurosci 23: 9852-9861.

Washizaki K, Smith QR, Rapoport SI, Purdon AD (1994). Brain arachidonic acid incorporation and precursor pool specific activity during intravenous infusion of unesterified $[3 \mathrm{H}]$ arachidonate in the anesthetized rat. J Neurochem 63: 727-736.

Weerasinghe GR, Rapoport SI, Bosetti F (2004). The effect of chronic lithium on arachidonic acid release and metabolism in rat brain does not involve secretory phospholipase $A_{2}$ or lipoxygenase/cytochrome P450 pathways. Brain Res Bull 63: $485-489$.

Wei S, Ong WY, Thwin MM, Fong CW, Farooqui AA, Gopalakrishnakone $\mathrm{P}$ et al (2003). Group IIA secretory phospholipase $\mathrm{A}_{2}$ stimulates exocytosis and neurotransmitter release in 
pheochromocytoma-12 cells and cultured rat hippocampal neurons. Neuroscience 121: 891-898.

Weichel O, Hilgert M, Chatterjee SS, Lehr M, Klein J (1999). Bilobalide, a constituent of Ginkgo biloba, inhibits NMDAinduced phospholipase $\mathrm{A}_{2}$ activation and phospholipid breakdown in rat hippocampus. Naunyn Schmiedebergs Arch Pharmacol 360: 609-615.

Wenthold RJ, Prybylowski K, Standley S, Sans N, Petralia RS (2003). Trafficking of NMDA receptors. Annu Rev Pharmacol Toxicol 43: 335-358.

Williams JH, Errington ML, Lynch MA, Bliss TV (1989). Arachidonic acid induces a long-term activity-dependent enhancement of synaptic transmission in the hippocampus. Nature 341: 739-742.

Wong EH, Kemp JA, Priestley T, Knight AR, Woodruff GN, Iversen LL (1986). The anticonvulsant MK-801 is a potent $N$-methyl-Daspartate antagonist. Proc Natl Acad Sci USA 83: 7104-7108.
Wong EH, Knight AR, Woodruff GN (1988). [3H]MK-801 labels a site on the $N$-methyl-D-aspartate receptor channel complex in rat brain membranes. J Neurochem 50: 274-281.

Yang HC, Mosior M, Johnson CA, Chen Y, Dennis EA (1999). Group-specific assays that distinguish between the four major types of mammalian phospholipase $\mathrm{A}_{2}$. Anal Biochem 269: 278-288.

Yegin A, Akbas SH, Ozben T, Korgun DK (2002). Secretory phospholipase $\mathrm{A}_{2}$ and phospholipids in neural membranes in an experimental epilepsy model. Acta Neurol Scand 106: 258-262.

Zarate Jr CA, Du J, Quiroz J, Gray NA, Denicoff KD, Singh J et al (2003). Regulation of cellular plasticity cascades in the pathophysiology and treatment of mood disorders: role of the glutamatergic system. Ann NY Acad Sci 1003: 273-291.

Zeise ML, Kasparow S, Zieglgansberger W (1991). Valproate suppresses $N$-methyl-D-aspartate-evoked, transient depolarizations in the rat neocortex in vitro. Brain Res 544: 345-348. 